\title{
DRINKING WATER QUALITY SIMULATION IN ALMONSHA DISTRIBUTION NETWORK
}

\section{Ahmed K.A. Ahmed*, Ahmed A. Mohamed**, Ali A.M. Gad**, and Mohamed E. El- dardeer ${ }^{* * *}$}

Email: aligad10@yahoo.com, akhaled0@yahoo.com

* Demonstrator, Civil Engineering Department, Sohag University

** Associate professor, Civil Engineering Department, Assiut University.

*** Lecturer, Civil Engineering Department, Assiut University

(Received October 13, 2009 Accepted October 31, 2009).

Water quality in distribution systems has become a prominent issue in the study of water networks. This study concentrates on chlorine disinfection as an indicator of water quality. The model discussed in this work is based on laboratory and field collected data. The model is applied on a real network which exists in Almonsha city in Upper Egypt. The experimental set-up and procedure of measuring bulk $(\mathrm{Kb})$ and wall $(\mathrm{Kw})$ chlorine decay coefficients are described. The collected field data together with experimental results are used for calibrating the model using extended period simulation. The aim of this study is to find a solution for the absent of the free residual chlorine in several sections of Almonsha water distribution network. The diurnal variations of domestic water consumption are taken into consideration. Also, different values have been assigned for the daily water consumption for both rural and urban zones of the network. Different water resources (surface and underground water) have been involved in the model. Underground water reservoirs and high elevated tanks are included in the simulation. The water level in the high elevated tanks and water table in the feeding wells are studied. The free residual chlorine concentrations (FRCCs) were measured at different sections of the network and used for the model calibration. FRCCs have been simulated in different locations of the network at several times using extended period simulation. The results of the field and experimental works have shown that, the initial chlorine concentration $(\mathrm{CO})$ has an effect on $\mathrm{Kb}$, an equation is derived to express the relation between them. Also, another equation is derived for the relation between $\mathrm{CO}$ and $\mathrm{Kw}$. The simulation process was extended for several months to dispose the effect of the initial conditions. It is found that, with the existing system of chlorine injection, some parts of the network keep nil values of FRCC even with an injected free residual chlorine dose reaching to $5 \mathrm{mg} / \mathrm{L}$ at the feeding point. A new technique is proposed. This technique is based on superposition method for chlorine disinfection. Finally, with the superposition method, it is found that, the minimum injected chlorine dose which should be injected at the feeding points ranges between $0.83 \mathrm{mg} / \mathrm{L}$ to $2 \mathrm{mg} / \mathrm{L}$. This dose is found to be sufficient to keep the minimum FRCC with values not less than $0.3 \mathrm{mg} / \mathrm{L}$ for the whole parts of the concerned network at all day hours 
KEYWORDS: Water quality; Disinfection; Residual chlorine; Distribution networks; Extended period simulation

\section{INTRODUCTION}

Good quality captured water, efficient disinfection, and residual disinfectant concentrations maintenance during transportation, are considered to be sufficient to keep consumers satisfied and avoid troubles in their health. Nevertheless, water treatment is not enough to guarantee excellent water quality to consumers, because storage, transportation, and distribution conditions can introduce contamination in many ways [8]. Disinfection is the water treatment process carried out to destroy any harmful micro-organisms that are contained in the drinking water. Chlorine is the most commonly used disinfectant due to its ease of application and monitoring, its low cost, and its effectiveness in killing bacteria [6]. When a chlorine dose is added to water, a part of it known as the chlorine demand readily reacts with reduced inorganics and easily oxidized organics. The excess of chlorine dose over the chlorine demand is called "residual chlorine". In order to prevent bacterial regrowth, it is desirable to maintain a detectable residual chlorine concentration (RCC) in the network. However, as a result of residual chlorine reaction with various substances in water and on pipe walls, its concentration may decay as it travels through the distribution system.

The U.S. Environmental Protection Agency (EPA) enforces regulations regarding the minimum residual chlorine, which must be presented in drinking water distribution networks (DWDNs). The Safe Drinking Water Act of 1974 and its amendments in 1986 state that a measurable RCC (typically assumed to be $0.20 \mathrm{mg} / \mathrm{l}$ ) must present at points of water consumption. On the other hand, the RCC should not be needlessly large since a large RCC may not appreciably reduce the health risk of pathogen exposure (compared to small residuals in the $0.20 \mathrm{mg} / \mathrm{l} \mathrm{range}$ ), while at the same time reactions of chlorine with certain naturally occurring organic compounds produce byproducts, including trihalomethanes (THMs), which are suspected carcinogens [16].

In fact, the water supply industry is being asked to shift their focus from water line delivering capacities to water quality changes when evaluating a water network system. Quality control through the modeling of water quality in distribution networks is a relatively new field. Water quality models have a wide range of uses, including understanding the effect of system operation on water quality, calibrating hydraulic networks, sizing and locating rechlorination facilities, identifying monitoring locations, and tracking historical water quality problems. Basically, water quality modeling is simulated either in a steady (snapshot) or a dynamic (extended period) environment. In steady state modeling, the external conditions of a distribution network are constant in time and the nodal concentrations of the constituents that will occur if the system is allowed to reach equilibrium are determined.

In dynamic models the external conditions are temporally varied and the time varying nodal concentrations of the constituents are determined [9]. Among recent water quality models, the EPANET's model has received rather wide acceptance by municipalities, [1]. 
The purpose of this study is to introduce a reliable approach for optimising residual chlorine concentrations (RCCs) within a real drinking water distribution network (DWDN) to maintain consistent detectable residual chlorine for pathogens control, without using excess disinfectant to minimize costs, potential health effects, and reduce taste and odour complaints. In this study, EPANET software is used for modelling chlorine decay in Almonsha DWDN through a first-order kinetic law.

\section{THEORETICAL APPROACH}

\subsection{Decay Reactions of Residual Chlorine}

The loss of RCC along drinking water distribution networks (DWDNs) is processed in two mechanisms as; chlorine reactions in bulk fluid and chlorine reactions with pipe walls. Transport of chlorine along the $i$ th pipe is given by the classical advection equation $[12,14]$ :

$$
\frac{\partial C_{i}}{\partial t}=-u_{i} \frac{\partial C_{i}}{\partial x}+r\left(C_{i}\right)
$$

where $C_{i}=R C C$ in pipe $i$ as a function of distance $x$ and time $t, u_{i}=$ mean flow velocity in pipe $i$, and $r=$ rate of residual chlorine reaction with both bulk fluid $\left(r_{b}\right)$ and pipe walls $\left(r_{w}\right)$ as a function of its concentration, $C_{i}$. The rate of residual chlorine bulk reaction, $r_{b}$, is commonly simulated by the following first-order decay equation [2]:

$$
r_{b}=-k_{b} C_{i}
$$

where $k_{b}$ is a bulk reaction rate coefficient. For first-order kinetics [13], the rate of residual chlorine wall reaction, $r_{w}$, can be expressed as:

$$
r_{w}=\frac{-4 k_{w} k_{f} C_{i}}{d\left(k_{w}+k_{f}\right)}
$$

where $k_{w}=$ wall reaction rate coefficient, $k_{f}=$ mass transfer coefficient, and $d=$ pipe diameter. While $k_{b}$ can be determined from laboratory measurements, $k_{w}$ is based on local residual chlorine measurements. Mass transfer coefficient, $k_{f}$, can be expressed in terms of a dimensionless Sherwood number, $S h$, as:

$$
k_{f}=S h \frac{D}{d}
$$

in which D is the molecular diffusivity of chlorine. In fully laminar flow, the average Sherwood number along the length of a pipe $(L)$ can be expressed as:

$$
S h=3.65+\frac{0.0668(d / L) \operatorname{Re} S c}{1+0.04[(d / L) \operatorname{Re} S c]^{2 / 3}}
$$


in which $\mathrm{Re}=$ Reynolds number and $S c=$ Schmidt number (kinematic viscosity of water divided by the diffusivity of chlorine). For turbulent flow, the empirical correlation of [10] is used:

$$
S h=0.0149 \operatorname{Re}^{0.88} S c^{1 / 3}
$$

\subsection{Hydraulic Model}

To conduct a quality simulation in a given DWDN, one must have a hydraulic model on which the quality model can be applied. Assume we have a pipe network with $N$ junction nodes and $N F$ fixed grade nodes (tanks and reservoirs). The flow-head loss relation in a pipe between nodes $i$ and $j$ can be given as:

$$
H_{i}-H_{j}=h_{i j}=a Q_{i j}^{f}+m Q_{i j}^{2}
$$

where $H=$ nodal head, $h=$ head loss, $a$ = resistance coefficient, $Q=$ flow rate, $f$ = flow exponent, and $m=$ minor loss coefficient. For pumps, the head loss (negative of the head gain) can be represented by a power law of the form

$$
h_{i j}=-\omega^{2}\left(h_{o}-b\left(Q_{i j} / \omega\right)^{\phi}\right)
$$

where $h_{o}$ is the shutoff head for the pump, $\omega$ is a relative speed setting, and $b$ and $\phi$ are the pump curve coefficients. The second set of equations that must be satisfied is the flow continuity around all nodes, $N$ :

$$
\sum_{j} Q_{i j}-D_{i}=0 \quad \text { for } i=1, \ldots \ldots \ldots N
$$

where $D_{i}$ is the flow demand at node $i$ and by convection, flow into a node is positive. The method used in EPANET to simultaneously solve the head loss and flow continuity equations, Eq.(7) and Eq.(8), that characterize the hydraulic state of the pipe network at a given point in time is called "gradient method" [15]. For extended period simulation, EPANET 's hydraulic model computes junction heads and link flows for a fixed set of reservoir levels, tank levels, and water demands over a succession of points in time. From one time step to the next, reservoir levels and junction demands are updated according to their prescribed time patterns while tank levels are updated using the current flow solutions.

\subsection{Water Quality Model}

EPANET 's water quality simulator uses a Lagrangian time-based approach to track the fate of discrete parcels of water as they move along pipes and mix together at junctions between fixed-length time steps. For each water quality time step, the contents of each segment are subjected to reactions, a cumulative account is kept of the total mass and flow volume entering each node, and the positions of the segments are updated. The chlorine concentration leaving the junction is simply the flow-weighted 
sum of the concentrations from inflowing pipes and external sources. For a specific node $k$ one can write:

$$
C_{i \mid x=0}=\frac{\sum_{j \varepsilon l_{k}} Q_{j} C_{j \mid x=L_{j}}+Q_{k, \text { ext }} C_{k, \text { ext }}}{\sum_{j \in I_{k}} Q_{j}+Q_{k, \text { ext }}}
$$

where $i=$ link with flow leaving node $k, I_{k}=$ set of links with flow into $k, L_{j}=$ length on link $j, Q_{j}=$ flow rate in link $j, Q_{k, \text { ext }}=$ external source flow entering the network at node $k$, and $C_{k \text {, ext }}=$ concentration of the external flow entering at node $k$. The notation $C_{i \mid x=0}$ represents the concentration at the start of link $i$, while $C_{i \mid x=L_{i}}$ is the concentration at the end of the link. The concentration throughout a storage tank, under completely mixed conditions is a blend of the current contents and that of any entering water. At the same time, the internal concentration could be changed due to reactions, $r\left(C_{s}\right)$. Mass balance at the storage tanks is given by:

$$
\frac{\partial\left(V_{s} C_{s}\right)}{\partial t}=\sum_{i \varepsilon I_{s}} Q_{i} C_{i \mid x=L_{i}}-\sum_{j \in O_{s}} Q_{j} C_{s}+r\left(C_{s}\right)
$$

where $V_{s}=$ storage volume at time $t, C_{s}=$ concentration within the storage facility, $I_{s}=$ set of links providing flow into the facility, and $O_{s}=$ set of links withdrawing flow from the facility. When EPANET 's quality model is applied to a network as a whole, Eq.(1) and Eq.(9) are solved for $C_{i}$ in each pipe $i$ and $C_{s}$ in each storage facility $s$. The solution is subjected to the initial conditions that specify $C_{i}$ for all $x$ in each pipe $i$ and $C_{s}$ in each storage facility $s$ at time 0 . Also, the solution is subjected to boundary conditions that specify values for $C_{k \text {, ext }}$ and $Q_{k \text {, ext }}$ for all time $t$ at each node $k$, which has external mass inputs. The hydraulic simulation model provides the volume $V_{s}$ in each storage facility $s$ and the flow rate $Q_{i}$ in each link $i$ at all time $t$. From one-step to the next the water quality in each segment, link, node, and tank are updated.

\section{MATERIALS AND METHODS}

\subsection{Case Study}

The chosen network was Almonsha network, which serves Almonsha city and its villages. The network contains two water resources (underground and surface water), 68 main pipes, 14 well pumping stations, Almonsha surface water purification plant, 20 elevated tanks, and 43 junctions as shown in Fig. (1). The groundwater table was found to be at $3.5 \mathrm{~m}$ under the ground surface. The network involves two kinds of 
pipes (asbestos and pre-stressed concrete), rely on its diameter. The pipes with diameter less than $600 \mathrm{~mm}$ are asbestos and other pipes are pre-stressed concrete.

In this network, FRCC isn't found at far nodes even the chlorine dose at the source is increased. This study tries to give an interpolation for this phenomenon and gives a suitable solution.

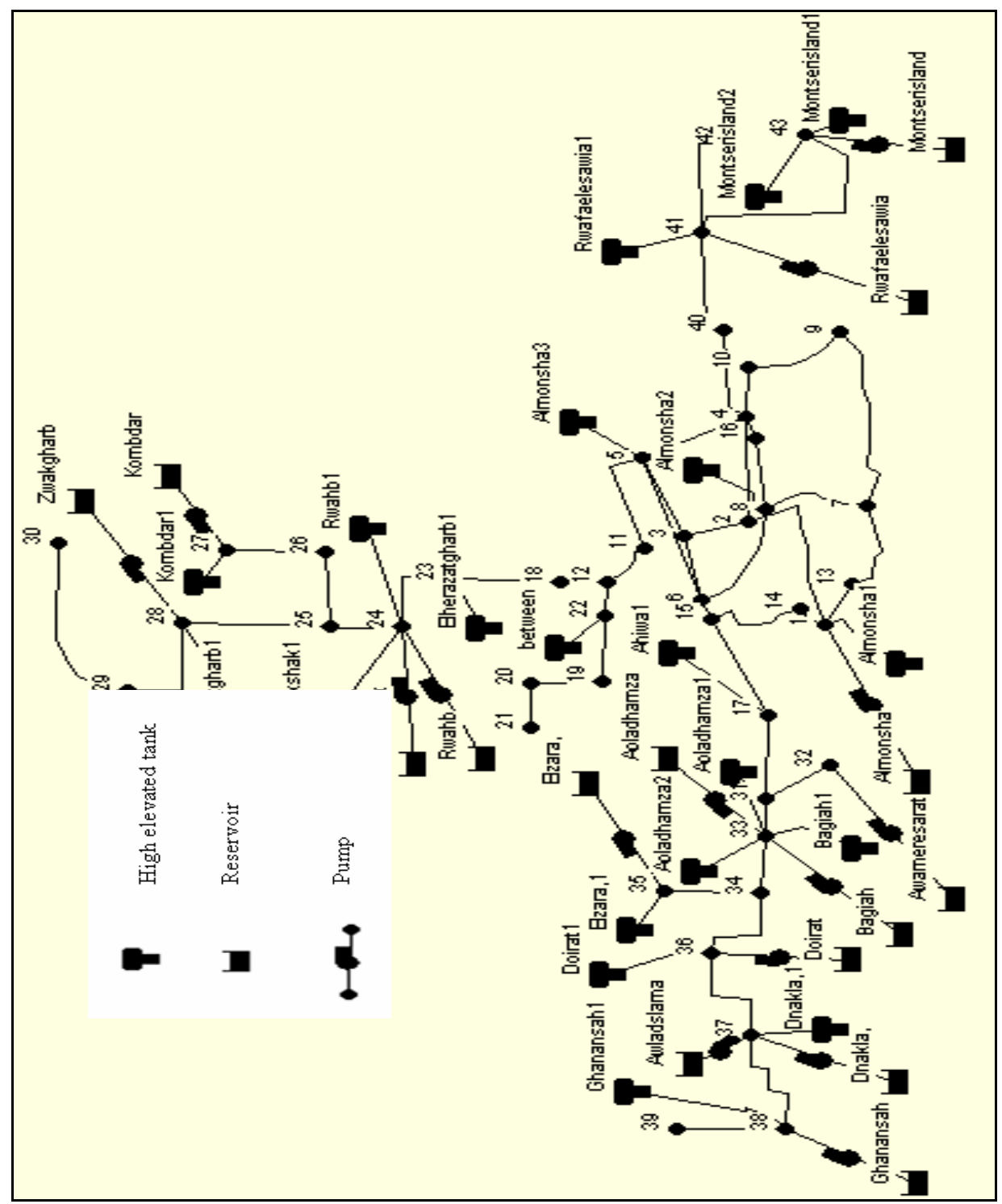

Table (1) gives the pumping station name, number of main and standby pumps, power of each pump, discharge, and head for each pump. Error! Reference source not found.) summarizes characteristics of elevated tanks as; capacity, diameter, elevation, minimum, and maximum water level 
Table (1) Characteristics of the involved pumping stations.

\begin{tabular}{|c|c|c|c|c|c|}
\hline Station name & $\begin{array}{r}\mathrm{No} \\
\text { main }\end{array}$ & $\begin{array}{l}\text { Pump } \\
\text { standby }\end{array}$ & $\begin{array}{l}\text { Power for } \\
\text { each pump } \\
\text { (HP) }\end{array}$ & $\begin{array}{l}\text { Discharge for } \\
\text { each Pump } \\
\left(\mathrm{m}^{3} / \mathrm{h}\right)\end{array}$ & $\begin{array}{c}\text { Head } \\
(\mathrm{m})\end{array}$ \\
\hline Almonsha & 2 & 2 & 250 & 720. & 35 \\
\hline Rewahib & 3 & 2 & 30 & 70 & 41 \\
\hline Zwak Shark & 3 & 2 & 30 & 70 & 41 \\
\hline Kom Bdar & 4 & 2 & 30 & 70 & 42 \\
\hline Zwak Gharb & 4 & 2 & 30 & 70 & 42 \\
\hline Awamer Elesarat & 2 & 1 & 30 & 70 & 36 \\
\hline Bagiah & 3 & 2 & 30 & 70 & 42 \\
\hline Aolad Hamza & 1 & 1 & 30 & 75 & 36 \\
\hline Elzara, & 2 & 1 & 30 & 70 & 39 \\
\hline Doirat & 4 & 2 & 30 & 70 & 42 \\
\hline Dnakla, & 3 & 2 & 30 & 50 & 41 \\
\hline Awlad Slama & 5 & 3 & 30 & 60 & 46 \\
\hline Ghanansah & 5 & 3 & 30 & 70 & 45 \\
\hline Rwafa Elesawia & 2 & 1 & 30 & 70 & 38 \\
\hline Montser Island & 2 & 1 & 30 & 70 & 38 \\
\hline
\end{tabular}

Table (2) Characteristic of elevated tanks.

\begin{tabular}{||c|c|c|c|c|c|c|}
\hline \multirow{2}{*}{ Tank name } & \multirow{2}{*}{ Capacity $\left(\mathrm{m}^{3}\right)$} & \multirow{2}{*}{$\begin{array}{c}\text { Height } \\
(\mathrm{m})\end{array}$} & \multicolumn{2}{|c|}{ Water level $(\mathrm{m})$} & Diameter \\
\cline { 4 - 6 } & & & minimum & maximum & \\
\hline Almonsha1 & 1500 & 35 & 0.5 & 9.5 & 15 \\
\hline Almonsha2 & 1500 & 35 & 0.5 & 9.5 & 15 \\
\hline Almonsha3 & 60 & 37 & 0.5 & 3.5 & 5 \\
\hline between & 60 & 35 & 0.5 & 3.5 & 5 \\
\hline Rewahib1 & 60 & 35 & 0.5 & 3.5 & 5 \\
\hline Rwafa Elesawia1 & 60 & 34 & 0.5 & 3.5 & 5 \\
\hline Montser Island1 & 500 & 30 & 0.5 & 7 & 10 \\
\hline Montser Island2 & 250 & 30 & 0.5 & 5.5 & 8 \\
\hline Ahiwa1 & 60 & 35 & 0.5 & 3.5 & 5 \\
\hline Bagiah1 & 200 & 32 & 0.5 & 5.7 & 7 \\
\hline Aolad Hamza1 & 200 & 32 & 0.5 & 5.7 & 7 \\
\hline Aolad Hamza2 & 60 & 35 & 0.5 & 3.5 & 5 \\
\hline Elzara1 & 200 & 35 & 0.5 & 5.7 & 7 \\
\hline Doirat1 & 60 & 37 & 0.5 & 3.5 & 5 \\
\hline Dnakla1 & 60 & 35 & 0.5 & 3.5 & 5 \\
\hline Ghanansah1 & 60 & 35 & 0.5 & 3.5 & 5 \\
\hline Elherazat Gharb1 & 60 & 35 & 0.5 & 3.5 & 5 \\
\hline Zwak Shak1 & 60 & 35 & 0.5 & 3.5 & 5 \\
\hline Kom Bdar1 & 60 & 36 & 0.5 & 3.5 & 5 \\
\hline Zwak Gharb1 & 200 & 35 & 0.5 & 5.7 & 7 \\
\hline \hline
\end{tabular}


Four high elevated tanks located at different places on the network were chosen for observation (Almonsha3, Rwafa Elesawia1, Zwak Gharb1, and Doirat1 as shown in Fig. (1)). Four points located at different places on the network were chosen to be field quality monitoring points (Almonsha (16), Elherazat Shark (18), Doirat (36), and rwafa Elesawia (41) as shown in Fig. (1)), these chosen quality points were at places of air relief or drain valves. FRCC was taken to be our quality parameter.

\subsection{Experimental Procedure to Measure $\mathrm{K}_{\mathrm{b}}$.}

There is no standard test for measuring $\mathrm{K}_{\mathrm{b}}$, hence the following procedure was developed by [7] as follows:

1. Freshly cleaned glassware was filled with distilled water which had been dosed to $10 \mathrm{mg} / \mathrm{l}$ free chlorine using concentrated calcium hypochlorite solution and left to stand for 24 hours. It was then emptied, rinsed thoroughly with distilled water and left to dry.

2. A 2.5 liter Winchester bottle was filled with the sample water and left for 15 min to ensure homogeneity.

3. The sample water was decanted into twenty $50-\mathrm{ml}$ glass bottles and sealed with glass stoppers.

4. All bottles were stored in an incubator, ideally set at the temperature of the sample water. Samples taken in the field were stored on site in an incubator and transferred to the laboratory in an insulated box.

5. The chlorine concentration was measured at intervals from the bottles. The intervals were ideally set so that the chlorine concentration fell by $10 \%$ of the initial reading between measurements, also closed bottles were used only one time after opening to measure chlorine concentration at this time.

6. The decay constants were then calculated after optimizing their values to minimize the sum of the squared errors between the modeled and observed chlorine concentrations, as:

$\mathrm{C}=\mathrm{C}_{0} \exp (-\mathrm{kt})$

where $\mathrm{k}=\mathrm{k}_{\mathrm{b}}+\mathrm{k}_{\mathrm{w}}, \mathrm{k}$ is the first order chlorine decay constant $(1 / \mathrm{h}), \mathrm{K}_{\mathrm{b}}$ is the bulk first order chlorine decay constant $(\mathrm{l} / \mathrm{h}), \mathrm{k}_{\mathrm{w}}$ is the wall first order chlorine decay constant $(\mathrm{l} / \mathrm{h}), \mathrm{C}$ is the free residual concentration after elapsed time $(\mathrm{t})$, and $\mathrm{C}_{0}$ is the initial free residual chlorine concentration. For the above experiment $\mathrm{k}_{\mathrm{w}}=0$ because glass bottles was used so that equation turn to:

$$
\mathrm{C}=\mathrm{C}_{0} \exp \left(-\mathrm{k}_{\mathrm{b}} \mathrm{t}\right)
$$

This test was made for measuring $\mathrm{K}_{\mathrm{b}}$ at different initial chlorine concentrations $2.1,1.5,1.06,0.83$, and $0.35 \mathrm{mg} / \mathrm{L}$. These tests were made at the laboratory of Almonsha water purification plant. In these tests DR/2000 Spectrophotometer instrument was used to measure FRCC.

\subsection{Experimental Procedure to Measure $\mathrm{K}_{\mathrm{w}}$}

The in-situ chlorine wall decay rate between any two points A and B can be measured, [11] as follows: 
1. The bulk decay rate constant was measured at point A.

2. The average upstream or initial chlorine concentration $\left(\mathrm{C}_{0}\right)$ was measured for a slug of water at point A over $\approx 20 \mathrm{~min}$.

3. The travel time, $t$; was calculated from point A to point B for that slug of water. This was obtained either from flow meter records or from tracer studies.

4. The downstream or final chlorine concentration (C) was measured as the slug of water arrived at point $\mathrm{B}$. An average over $\approx 20 \mathrm{~min}$ was taken to ensure that the correct slug of water was measured. If a tracer study was used to calculate the travel time, then the period immediately prior to the trace being observed was used as the final chlorine concentration.

5. The overall and wall first-order decay rate constants were then calculated from:

$$
\begin{aligned}
& \mathrm{k}=1 / \mathrm{t} * \ln \mathrm{C} / \mathrm{C}_{0} \\
& \mathrm{k}_{\mathrm{w}}=\mathrm{k}-\mathrm{k}_{\mathrm{b}}
\end{aligned}
$$

Sites suitable for measurement of in-situ $K_{w}$ were based on the following criteria:

- $\quad$ proximity to a chlorination point to ensure sufficient chlorine to measure;

- $\quad$ sufficient length to observe measurable decay;

- uniform pipe material and diameter to aid the interpretation of results; and

- $\quad$ safe and accessible sampling locations.

In this study two kinds of pipes (asbestos and pre-stressed concrete) were chosen to determinate $\mathrm{K}_{\mathrm{w}}$ by the previous way, these pipes have no branches on it between the first and second point $\mathrm{A}$ and $\mathrm{B}$.

For the pre-stressed concrete pipe, the main outlet pipe (diameter $=800 \mathrm{~mm}$ ) from Almonsha water purification plant was chosen to determinate $\mathrm{K}_{\mathrm{w}}$ for this kind of pipes, the first point on this pipe (A) was an air relief valve, second point (B) was a tap on the first branch on this pipe. The distance between the two points was $110 \mathrm{~m}$, and the velocity was $0.74 \mathrm{~m} / \mathrm{s}$. The traveling time between the two points was found to be 0.041 hour. Tests were begun with an initial chlorine concentration of $1.98 \mathrm{mg} / \mathrm{L}$, then repeated with $1.50,1.35,1.10$ and $0.93 \mathrm{mg} / \mathrm{L}$. For asbestos pipes, the main pipe line (diameter $=400 \mathrm{~mm}$ ) which use to transport water from Almonsha town to Rwafaelesawia village was chosen to determine $K_{w}$ for this kind of pipes. The first point on this pipe (A) was an air relief valve, second point (B) was a drain valve, the distance between the two points was $1053 \mathrm{~m}$, and the velocity was $0.3 \mathrm{~m} / \mathrm{s}$, so the traveling time between the two points was 0.975 hour. Tests were begun with initial chlorine concentration $0.88 \mathrm{mg} / \mathrm{L}$, then repeated with $0.71,0.62,0.44$ and $0.305 \mathrm{mg} / \mathrm{L}$. The apparatus that was used to measure free residual chlorine in these tests was 941 colorimeter.

\subsection{Hydraulic Simulation Suppositions}

A diurnal curve that makes water demands at the junction nodes of the used drinking water distribution networks varies in a periodic way over the course of the day has to be used to make the network more realistic for analyzing an extended period of operation. For the average day flow, the diurnal demand curve that is observed by [4] and used for simulation in this study is shown in Fig. (2). The curve provides demand 
peaking factors as the multipliers that are applied to the average base demand given for each junction node in the drinking water distribution networks to determine its actual demand in a given time period.

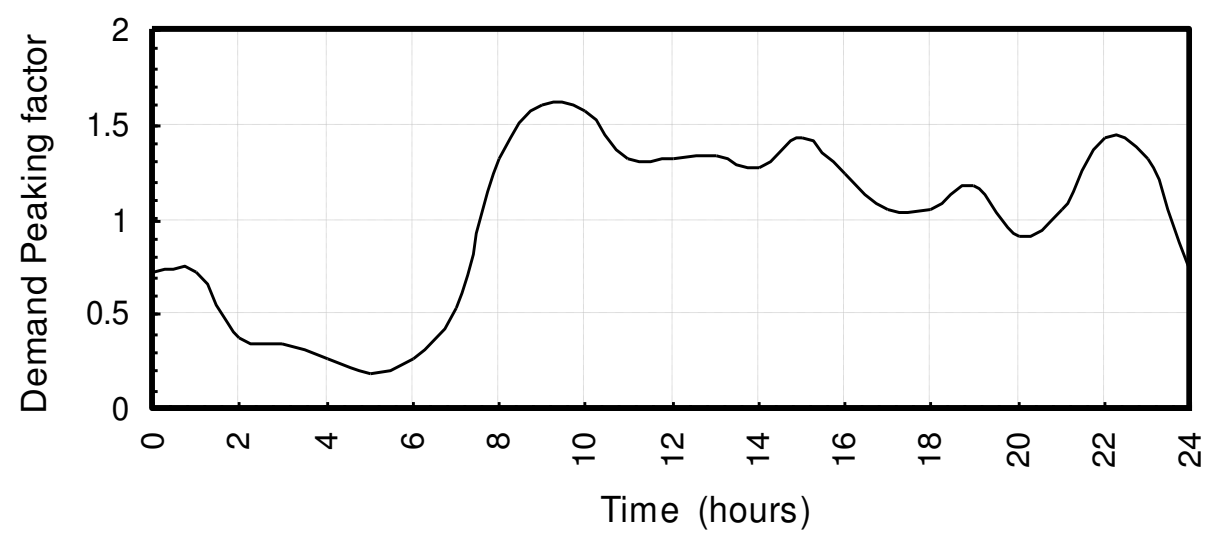

Fig. (2) Diurnal demand curve for extended period simulation.

Average base demands for junction nodes were calculated by multiplying number of people drinking from these nodes by average water consumption per capita. Average water consumption of $140 \mathrm{~L} / \mathrm{c} / \mathrm{d}$ for Almonsha city and $80 \mathrm{~L} / \mathrm{c} / \mathrm{d}$ for villages are assumed. Population numbers were taken from [3].

EPANET Program can use different shapes of pump curve depending on the number of points supplied. Single-Point curve was used in this research, single point from Table (1) was entered to model.

Wells in the used network are confined wells full penetration, so from the field data, dynamic water level was computed for each well while pumps were working by assuming that:

1. Starting water level is still constant at every time pumps start.

2. Ending water level was computed from the static equation (14) and then difference between starting and ending water level was divided equally through the pump working time to estimate water level at every hour.

$$
Q=\frac{2 \pi b k(H-h)}{\ln (R / r)}
$$

where $\mathrm{H}$ is the starting water depth, $\mathrm{h}$ is the depth of water at the end time of the working period, $\mathrm{r}$ is radius of the well, $\mathrm{k}$ is the saturated permeability coefficient of the aquifer relies on the type of the soil, $\mathrm{R}$ is radius of the influence circle, and $\mathrm{b}$ is thickness of the aquifer.

Figure (3) shows water level variations with time for Awamer-Elesarat well in Almonsha DWDN as an example. A daily computed water levels were used in the simulation. 


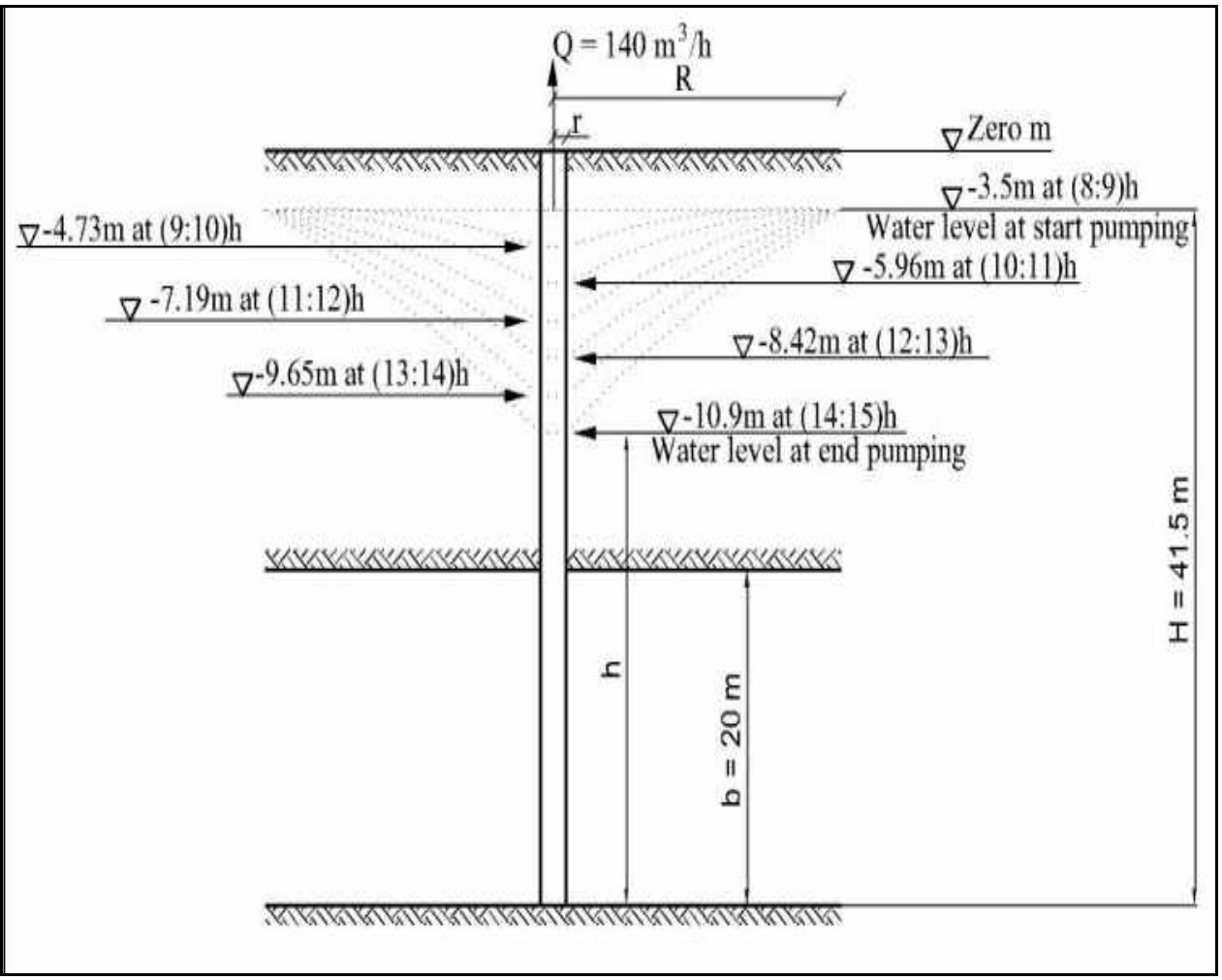

Fig. (3) Daily water table variation at Awamer-Elesarat pumping well.

\section{RESULTS AND DISCUSSIONS}

\subsection{Relationship between $\mathrm{C}_{0}$ and $\mathrm{K}_{\mathrm{b}}$.}

The main objective of the relationship between initial chlorine concentration $\left(\mathrm{C}_{0}\right)$ and bulk chlorine decay coefficient $\left(\mathrm{k}_{\mathrm{b}}\right)$ is to develop functional relationships that can be used to enhance the durability of network models, a series of relationships between free residual chlorine concentration $(\mathrm{C})$ and time $(\mathrm{t})$ at different $\mathrm{C}_{0}$ ranging from 0.35 to 2.1 $\mathrm{mg} / \mathrm{L}$ are plotted as shown in Fig. (4). This Figure illustrates that, for a constant $\mathrm{C}_{0}$, the free residual chlorine decreases with time $(\mathrm{t})$. An exponential relationship for the chlorine concentration $(\mathrm{C})$ as a function of the elapsed time $(\mathrm{t})$ for each initial chlorine concentration $\left(\mathrm{C}_{0}\right)$ could be obtained. The $\mathrm{K}_{\mathrm{b}}$ for each $\mathrm{C}_{0}$ was estimated. The results were compared and agreed with that of James [7].

For Almonsha water, Fig.(5) shows a linear relationship between $\mathrm{k}_{\mathrm{b}}$ and $\mathrm{C}_{0}$, this relation can be expressed through a general equation in the following form.

$$
\mathrm{K}_{\mathrm{b}}=-0.0967 \mathrm{C}_{0}+0.254
$$




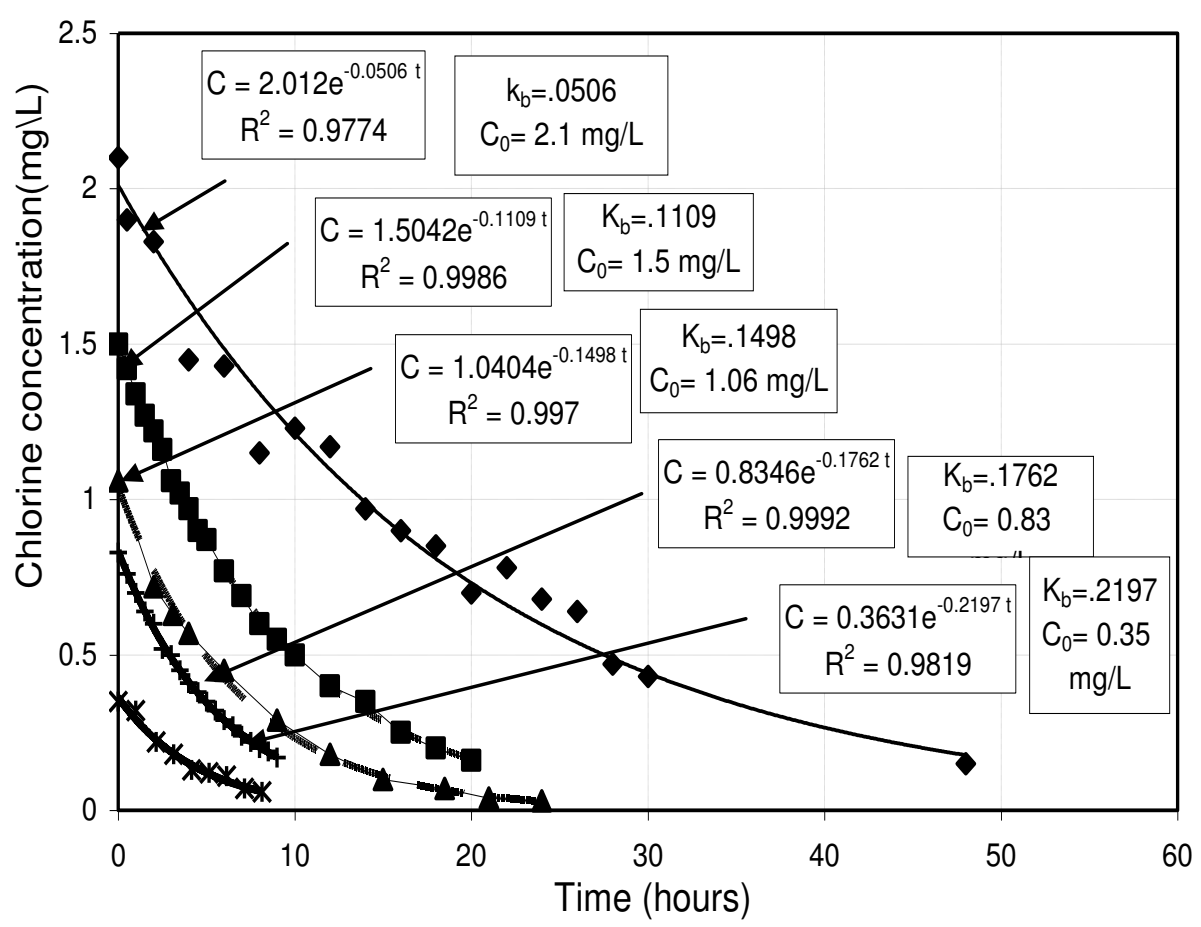

Fig. (4) Bulk chlorine decay coefficients at different initial chlorine concentrations.

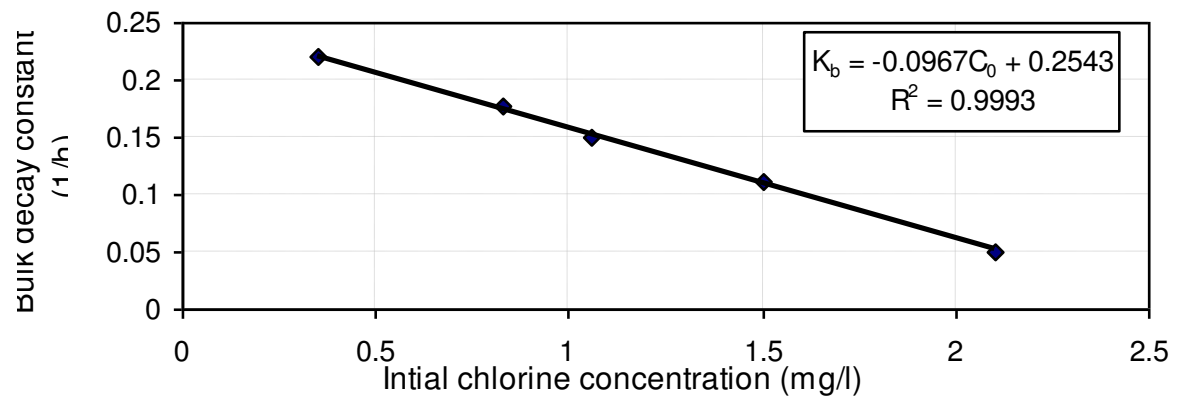

Fig. (5) Relation between the initial chlorine concentration and the bulk decay constant.

\subsection{Relationship between Initial Chlorine Concentration and Wall Chlorine Decay Coefficient.}

In order to study relationship between the initial chlorine concentration $\left(\mathrm{C}_{0}\right)$ and the wall chlorine decay coefficient $\left(\mathrm{K}_{\mathrm{w}}\right)$. The $\mathrm{K}_{\mathrm{w}}$ was measured at different $\mathrm{C}_{0}$ for every kind of pipes at Almonsha network.

For asbestos pipes in Almonsha network, the $\mathrm{K}_{\mathrm{w}}$ was measured at $\mathrm{C}_{0}$ equals to $0.305,0.44,0.62,0.71$, and $0.88 \mathrm{mg} / \mathrm{L}$. The relationship between $\mathrm{K}_{\mathrm{w}}$ and $\mathrm{C}_{0}$ is plotted as shown in Fig. (6). From this figure it is clearly noticed that for asbestos pipes $\mathrm{K}_{\mathrm{w}}$ 
decreases with increasing of the $\mathrm{C}_{0}$. The results were compared and agreed with that of Hallam [5]. $\mathrm{K}_{\mathrm{w}}$ can be expressed with $\mathrm{C}_{0}$ through a linear equation (16)

$$
\mathrm{K}_{\mathrm{w}}=-0.5411 \mathrm{C}_{0}+0.5224
$$

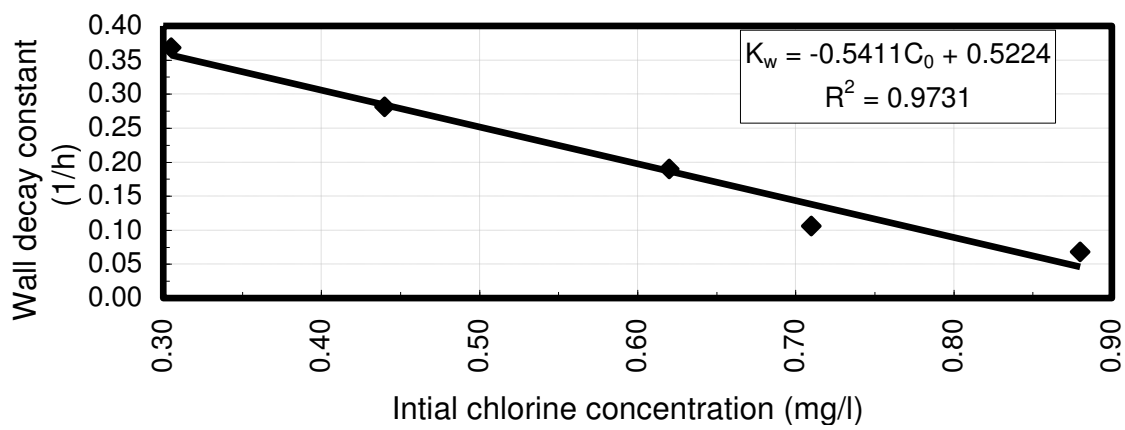

Fig. (6) Relation between $\mathrm{C}_{0}$ and $\mathrm{K}_{\mathrm{w}}$ for asbestos pipes.

For pre-stressed concrete pipes at Almonsha network, the $\mathrm{K}_{\mathrm{w}}$ was measured at $\mathrm{C}_{0}$ equals to $0.93,1.10,1.35,1.50$, and $1.98 \mathrm{mg} / \mathrm{L}$. The relationship between $\mathrm{K}_{\mathrm{w}}$ and $\mathrm{C}_{0}$ is plotted as shown in Fig. (7). From this figure it is clearly noticed that for pre-stressed concrete pipes $\mathrm{K}_{\mathrm{w}}$ decreases with increasing of $\mathrm{C}_{0}$. The results were compared and agreed with that of Hallam [5]. $\mathrm{K}_{\mathrm{w}}$ can be expressed with $\mathrm{C}_{0}$ through a linear equation (17).

$$
\mathrm{K}_{\mathrm{w}}=-1.4362 \mathrm{C}_{0}+2.5586
$$

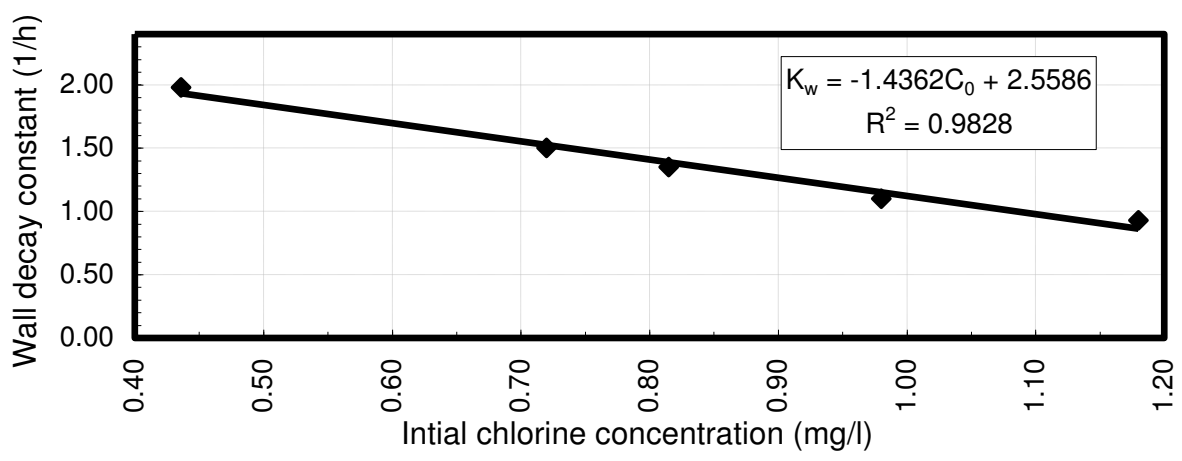

Fig. (7) Relation between $\mathrm{C}_{0}$ and $\mathrm{K}_{\mathrm{w}}$ for pre-stressed concrete pipes.

\subsection{Hydraulic Simulation}

The data and suppositions of Almonsha distribution network with the surrounding villages are used in the extended hydraulic simulation. An extended period simulation for a period of 480 days is performed to exclude the effect of the assumed initial conditions. Before the end of the simulation period the curves were found to be daily repeated. The outputs of the last day were only considered. 
The observed water level in the elevated tanks was considered as a proving parameter for the simulation process. The hydraulic simulation is achieved when the calculated data complies with the observed ones. The water table at the four high elevated tanks located at Rwafa Elesawia (1), Zwak Gharb (1), Doirat (1) and Almonsha (3) was observed for a complete one day. The first three elevated tanks locate out of Almonsha city while the fourth tank locates inside the city. In Figs. (8) through (11), the field observed head and the simulated results through a complete one day are plotted for the four tanks. From the figures, the observed and calculated heads are in good agreement.

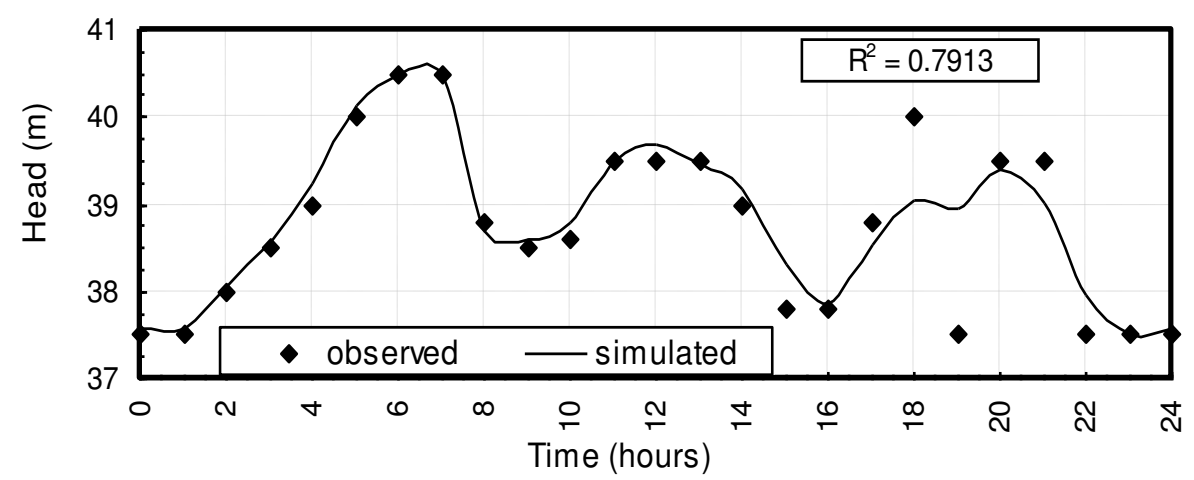

Fig. (8) Daily simulated and observed water level at the elevated tank of Almonsha 3.

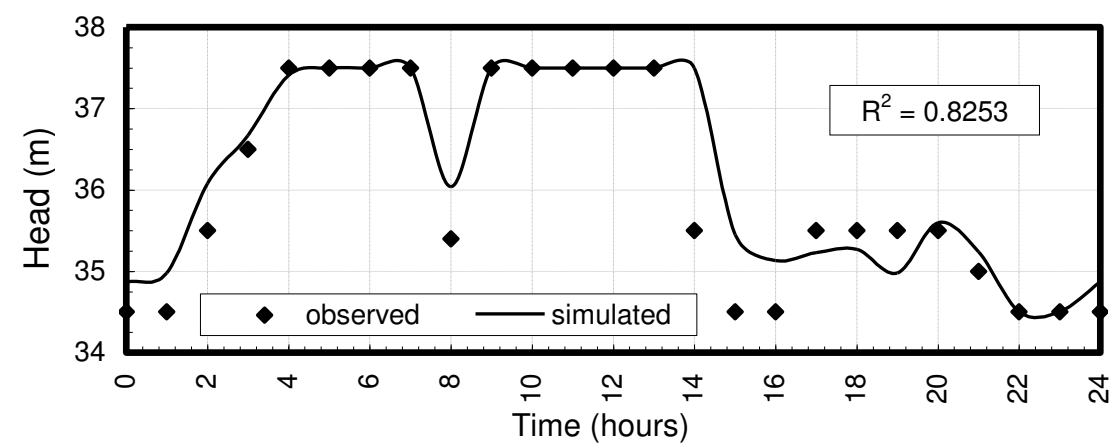

Fig. (9) Daily simulated and observed water level at the elevated tank of Rwafa Elesawia 1.

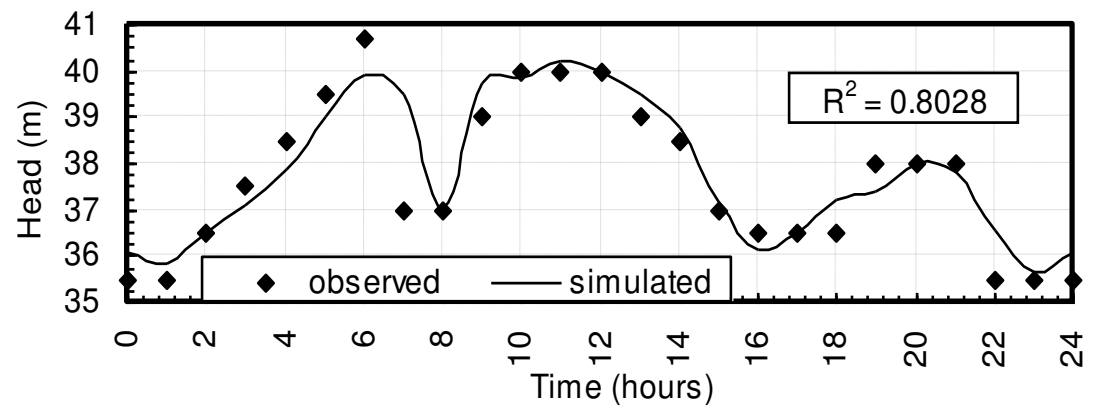

Fig. (10) Daily simulated and observed water level at the elevated tank of Zwak

Gharb1. 


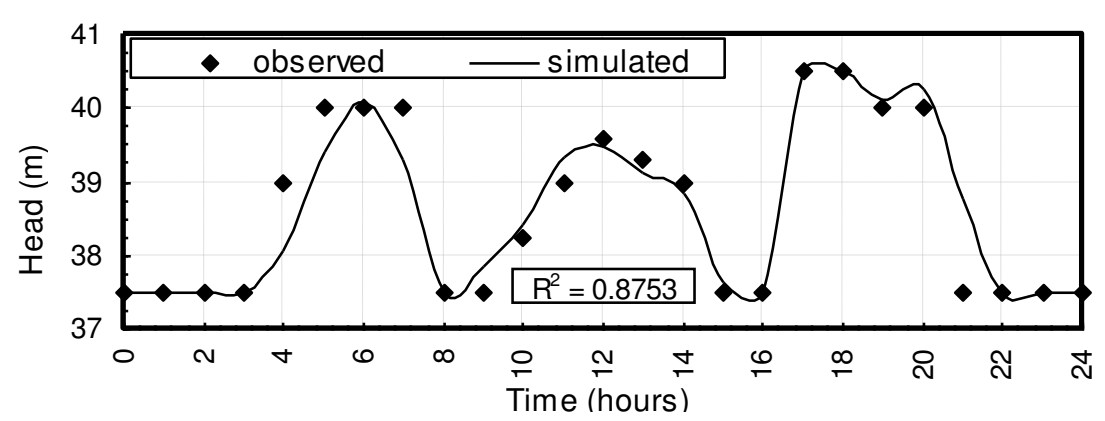

Fig. (11) Daily simulated and observed water level at the elevated tank of Doirat 1

The high elevated tanks (HETs) work as a balancing water storage for the distribution network. The water enters HETs when the produced amount of water becomes more than the consumed one. The variations of both consumed and produced discharges of water through 24 hours of simulation is shown in Fig.(12). From the figure, it is clear that the produced discharge is bigger than the consumed discharge for the first 6 hours of the day, then the process inverses for the following 5 hours and so on.

The difference between the produced and consumed discharges through the day gives the amount of the hourly in and out-flow of water from HETs as shown in Fig.(13). The accumulative amount of the in and out-flow of the water from HETs gives the storage values in the tanks as shown in Fig.(14). This figure illustrates that the storage values in HETs increases in the earlier hours of the day as the consumption rates are small. Also, it shows that the storage values decreases rapidly at the peak consumption hours and at the end of the day when the pumping wells are in rest.

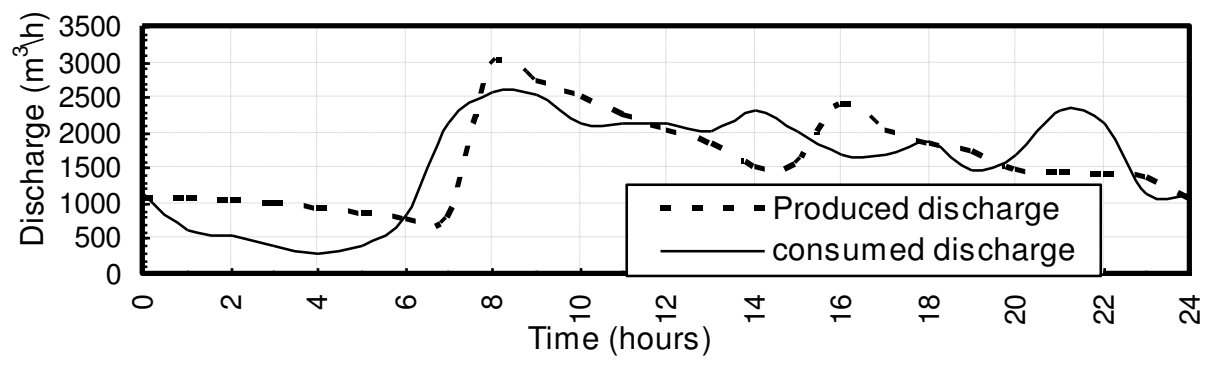

Fig. (12) Daily variations of the consumed and produced amount of water for Almonsha network

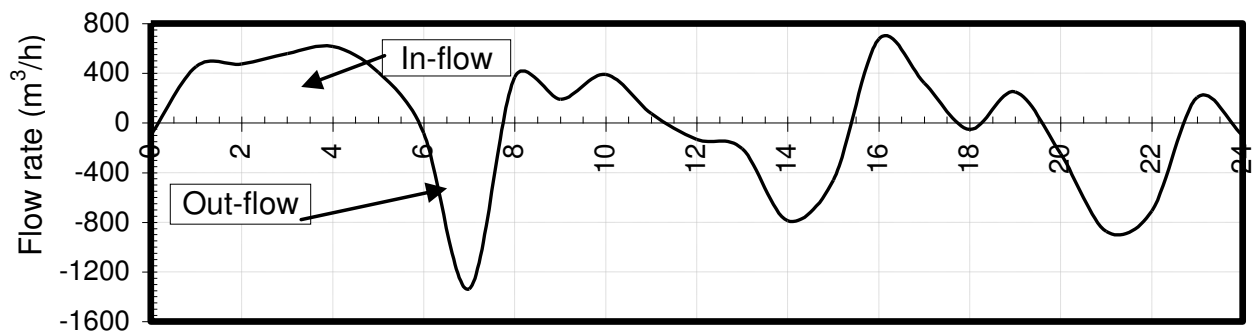

Day time (hrs)

Fig. (13) Daily In and out-flow of water from high elevated tanks. 


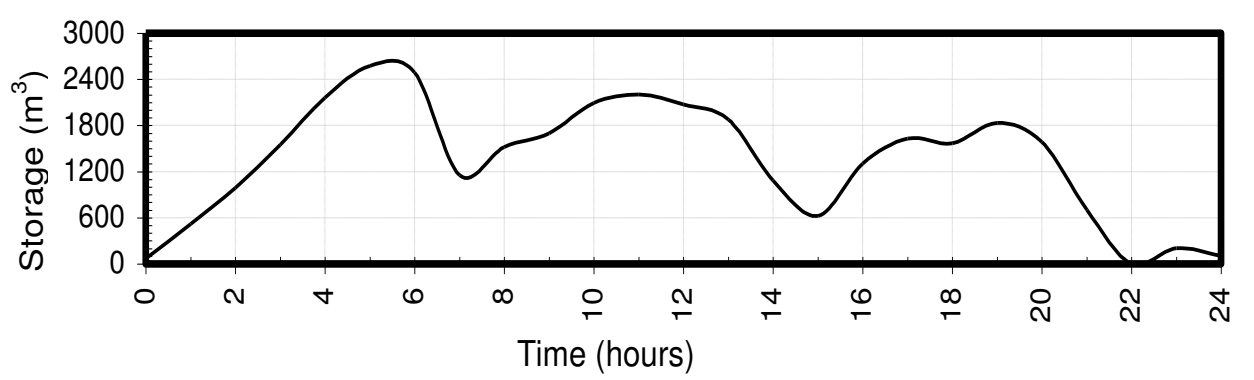

Fig. (14) Transient storage in elevated tanks through the day.

From the simulation, the pressure head at each node of the water distribution network could be calculated through the whole time of the day. Figure (15) shows the transient changes of the percent of nodes with heads less than values of $34,36,38,40$, and $42 \mathrm{~m}$ through the day. From the figure, it is clear that $20-30 \%$ of the nodes have a pressure head less than $36 \mathrm{~m}$ through out the day.

Also, it is clear that for a pressure head of $38 \mathrm{~m}$ the critical times are at 8:00 and 16:00 o'clock when the consumption reaches its peak values. For pressure heads of 40 and $42 \mathrm{~m}$ most of the network nodes have a pressure lack. Also, from the figure it is observed that a pressure lack occurs at time 0:00 as most of the pumping wells are in the rest time.

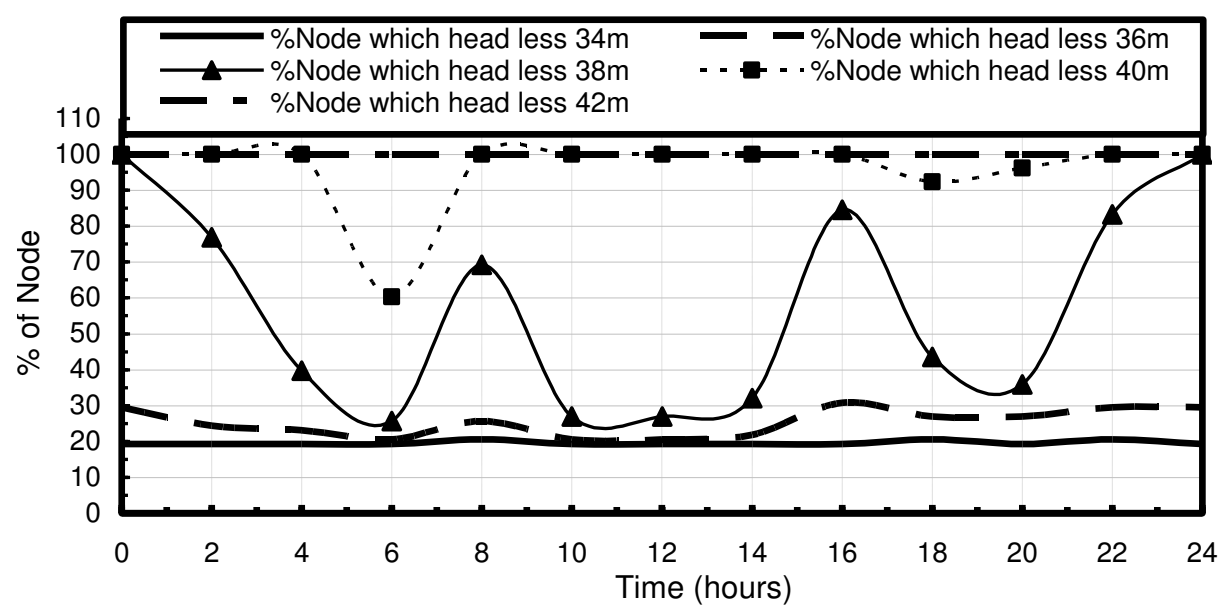

Fig. (15) Head categories for nodes

\subsection{Quality Simulation}

Quality simulation occurs when field data match the computed outputs. Elements hydraulic properties of Almonsha DWDN with free residual chlorine decay parameters $\left(\mathrm{K}_{\mathrm{b}}\right.$ and $\left.\mathrm{K}_{\mathrm{w}}\right)$ and $\mathrm{C}_{0}$ used for extended period simulation. For this simulation the only chlorine injection point was located at Almonsha water purification plant (WPP) with a constant dose of $1.5 \mathrm{mg} / \mathrm{L}$ of free residual chlorine. The network was both hydraulically and quality simulated. The observed and calculated FRCC are compared. 
Figure (16) illustrates comparison between the field data and simulated of the daily FRCC for nodes, Almonsha (16), Elherazat Shark (18), Doirat (36) and Rwafa Elesawia (41). This figure shows a good agreement between the field and simulated FRCC. For a constant free residual chlorine dose of $1.50 \mathrm{mg} / \mathrm{L}$ at Almonsha WPP, the transient changes in the percent of nodes which has FRCC less than $0.2 \mathrm{mg} / \mathrm{L}$ through 24 hours of simulation is illustrated as shown in Fig.(17).

It is clear from Fig.(17) that the percentage of the FRCC lack nodes increase at the mid day hours (from 9:00 to 16:00) i.e. the period when the feeding wells are working. The mainly reason for this lack is that there is no chlorine injection at the feeding wells, this can be concluded that there is a FRCC lack (a water quality problem) at around $40 \%$ of the nodes of Almonsha network through the whole times of the day.

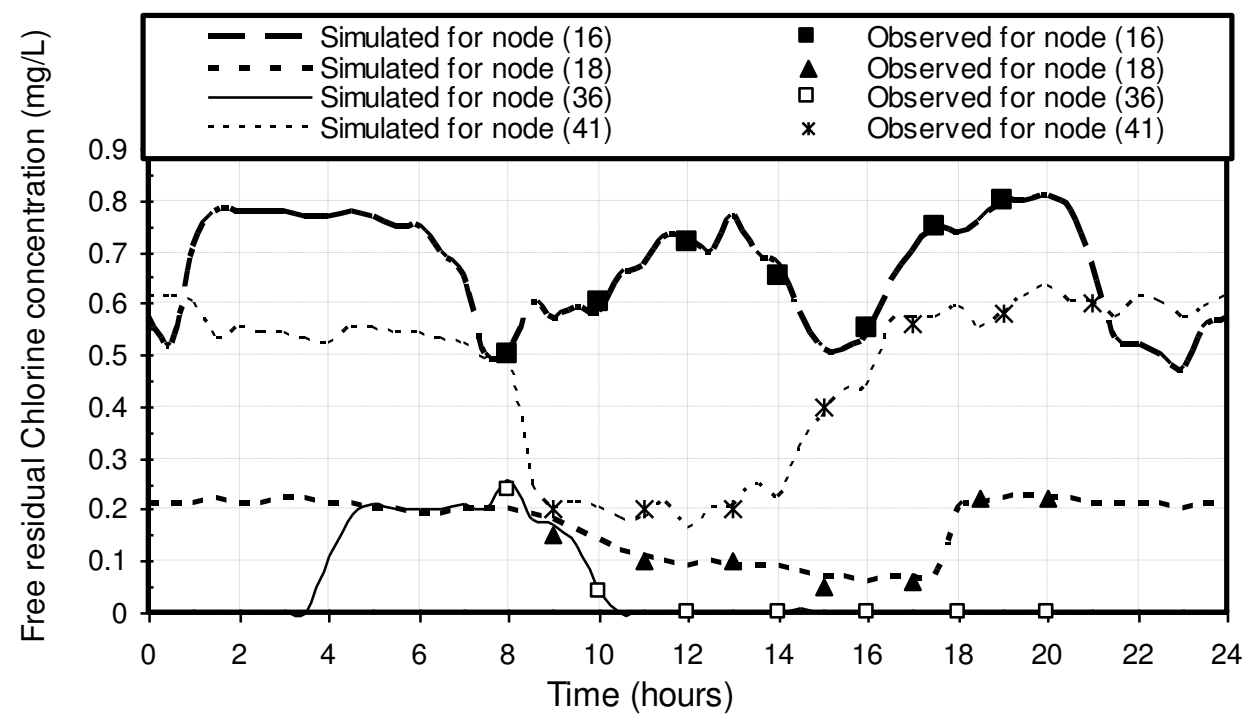

Fig. (16) Simulated and observed free residual chlorine concentration at nodes 16 , 18, 36, and 41 of Almonsha network

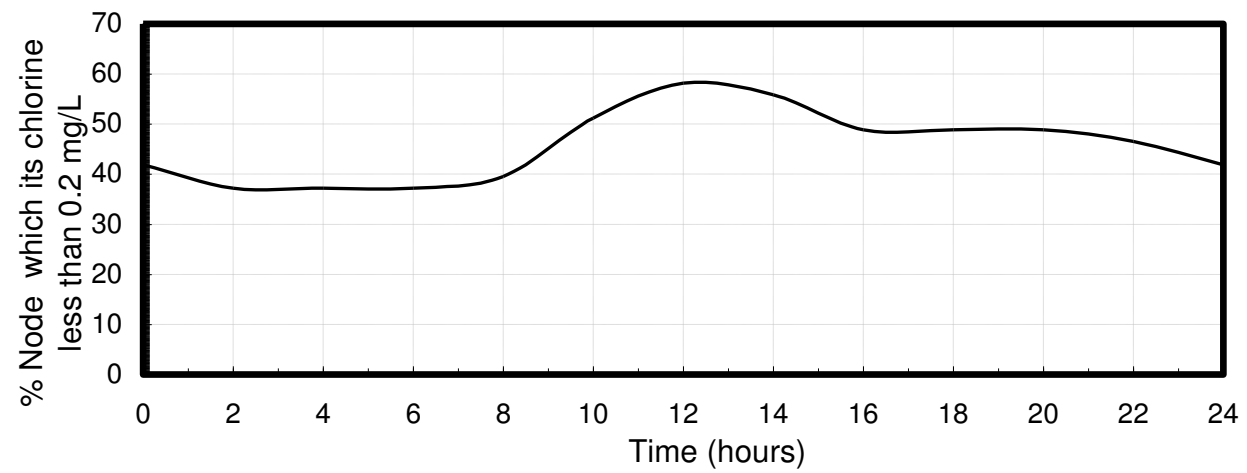

Fig. (17) Percent of nodes which it's FRCC less than $0.2 \mathrm{mg} / \mathrm{L}$ for chlorine dose of 1.5 $\mathrm{mg} / \mathrm{L}$ at Almonsha WPP only. 


\subsection{Increasing the Injected Chlorine Dose at Almonsha WPP}

The chlorine problem of Almonsha DWDN is that there is no chlorine concentration at the parties' nodes. The first thinking of the solution of the problem was to increase the injected chlorine dose at Almonsha WPP. According to this thinking the injected FRCC at Almonsha WPP $\left(\mathrm{C}_{0}\right)$ was increased to be $2,2.5$, and $5 \mathrm{mg} / \mathrm{L}$. For the numerical simulation chlorine decay coefficients $\left(\mathrm{K}_{\mathrm{b}}\right.$ and $\left.\mathrm{K}_{\mathrm{w}}\right)$ were calculated according to each value of $\mathrm{C}_{0}$. The transient changes of the percent of nodes which has FRCC less than $0.20 \mathrm{mg} / \mathrm{L}$ for different injected dose $(1.5,2,2.5$, and $5 \mathrm{mg} / \mathrm{L})$ at Almonsha WPP are illustrated in Fig.(18). From this figure, it is clear that there are no obvious changes of the percent of nodes with FRCC less than $0.20 \mathrm{mg} / \mathrm{L}$ with increasing the injected chlorine dose at the WPP.

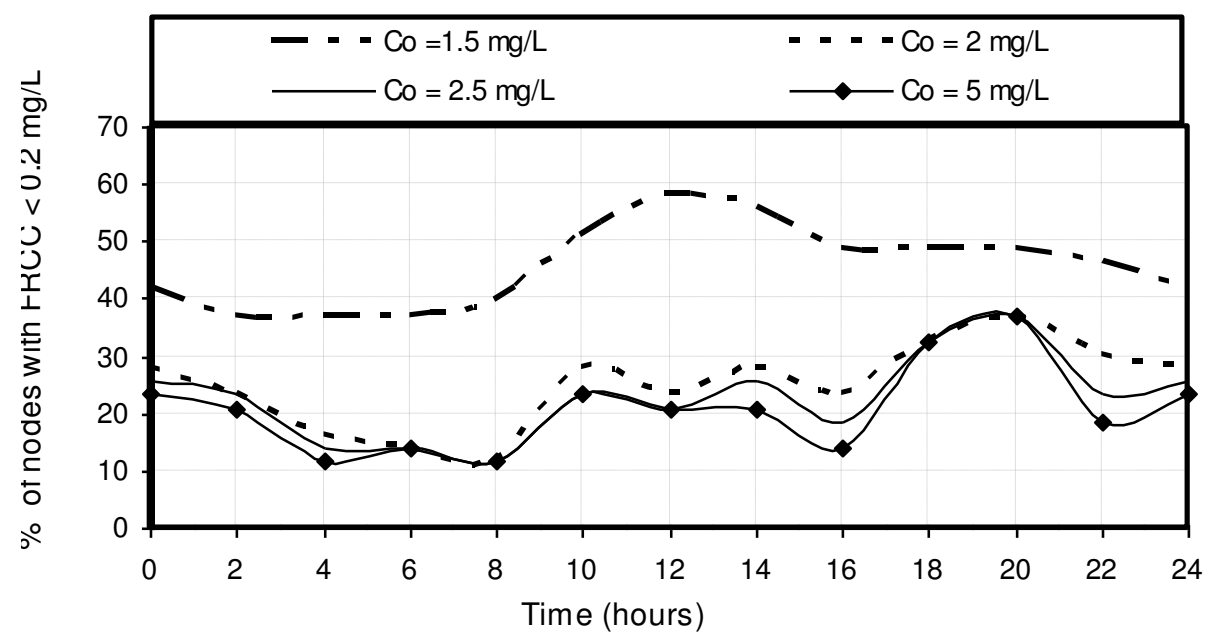

Fig. (18) Transient changes of the Percent of nodes which its FRCC are less than 0.2 $\mathrm{mg} / \mathrm{L}$ for different injected chlorine doses at Almonsha WPP.

\subsection{Superposition Chlorine Method Using Extended Period Simulation}

As mentioned before in the existing Almonsha DWDN there are nodes that haven't any free residual chlorine all over the day even with injecting high chlorine dose at Almonsha WPP (up to $5 \mathrm{mg} / \mathrm{L}$ ). The reason is that these nodes are feeded by unchlorinated underground water. From the numerical simulation it is found that the best solution is to add chlorine to the groundwater at the wells' location before the water reach to consumers. The added chlorine need a sufficient contact time for disinfection. Therefore, a storage tanks are needed beside the wells, and the pumped water should passes through high elevated tank (HET) as chlorine takes a detention time before going to consumers. Fortunately, there are HETs in closed locations to the feeding wells except at Awamer-ELesarat pumping station. The geometric properties (heightdiameter-water volume) of the existing HETs are taken in consideration. A supposed new HET at Awamer-ELesarat with properties similar to that one at Bagiah 1 pumping station is considered. 
The superposition chlorine method using extended period simulation can be briefly explained as:

1. Several parameters are considered such as:

a- All the hydraulic properties of the elements of Almonsha DWDN.

b- The daily variation of the drinking water consumption and the difference between urban and rural consumptions.

c- The variations of the chlorine decay coefficients with the initial chlorine concentrations are modeled.

d- The working daily hours of the feeding wells are considered in the simulation.

e- The variations of the groundwater table in the feeding wells before and through the pumps working times are calculated and modeled.

2. The pumped water is considered to be firstly pumped to the high elevated tanks before moving toward the consumers (water distribution network).

3. From the numerical simulation, the served region form each water feeding source could be estimated for the whole hours of the day.

4. The water distribution network of Almonsha was divided into a number of sub-networks such that each one is assigned to a water resource. The boundary of each sub-network may vary from an hour to another.

5. A concentration of FRCC was assumed to be available for the water which leaving the HETs to the served sub-network. Several trials of extended period simulation were performed with different concentrations of FRCC to get the minimum concentration which keeps the FRCC more than $0.20 \mathrm{mg} / \mathrm{L}$ through all times of the day at all points of the sub-network. This minimum concentration satisfies the WHO and Egyptian code conditions and produces the minimum amount of disinfection by-products.

6. The previous step (No.5) was done for each sub-network and a certain value of FRCC was estimated and assigned to each water resource.

7. The same procedure was performed for Almonsha WPP and a certain value was assigned for it.

8. The whole network with the proposed injected doses at all water resources was then simulated.

9. The FRCC in Almonsha water distribution network was periodically and spatially simulated.

The analysis and results of the extended period simulation of both individual sub-networks and the accumulated network of Almonsha can be discussed as follows:

- For example Zwak-Gharb sub-network is explained and the same procedure was made for each sub-network and a certain value of FRCC was estimated. In Zwak-Gharb, there are groundwaters feeding wells next to a high elevated tank with capacity of $200 \mathrm{~m}^{3}$ and height of $35 \mathrm{~m}$. In the existing system, the water is directly pumped from the wells to the water distribution network without any chlorine injection. In this method, the groundwater is assumed to be injected by a certain chlorine dose and pumped to the high elevated tank to get some detention time as a chlorine contact time after that it moves to consumers. The sub-network which is served by Zwak-Gharb wells is shown in Fig.(19). Using trace studies the transient daily changes of the percent of the water from Zwak-Gharb wells at each 
node of the network could be estimated as shown in Fig. (20). The transient daily changes of the percent of the water from Zwak-Gharb wells at each node of the network was multiplied by the diurnal demand curve to get a new diurnal demand curve for Zwak-Gharb sub-network at the concerned node, as shown in Fig.(21). After that, the sub-network of Zwak-Gharb wells was numerically simulated to get the minimum injected FRCC which conveys the conditions of the WHO and Egyptian code at all nodes through the day. Several trials with different injected chlorine doses at the feeding well were performed. Figure (22) shows the transient changes of the FRCC at nodes 25, 26, 27, 28, 29, and 30 for an injected FRCC of $1.80 \mathrm{mg} / \mathrm{L}$. From the figure, it clear that the FRCC at all nodes is safe for the whole time of the day.

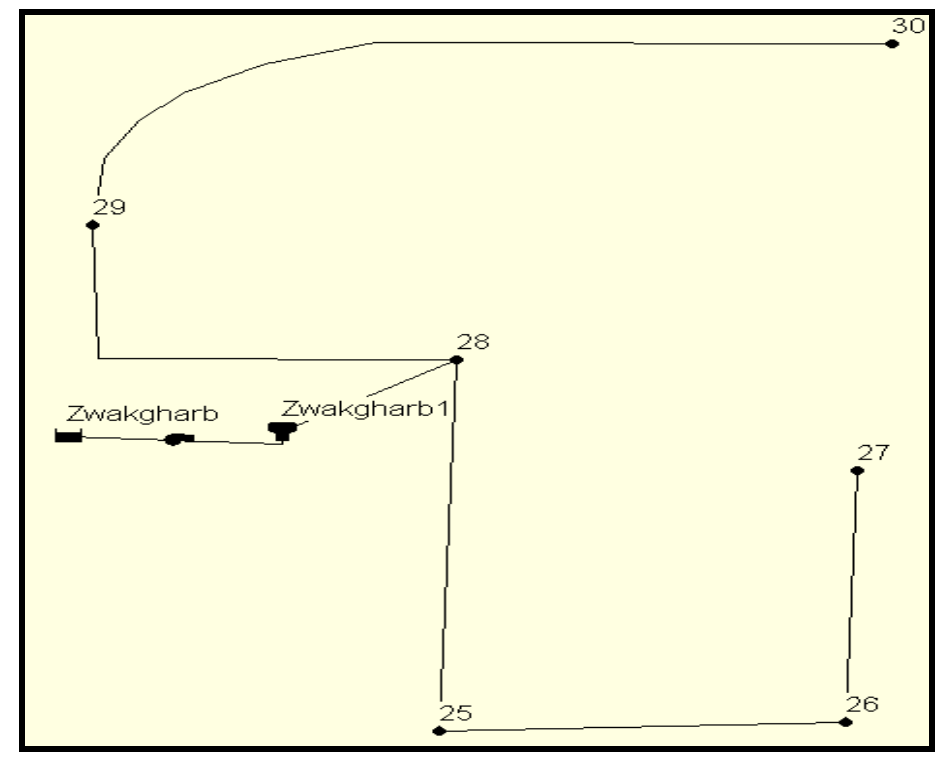

Fig. (19) Sub-network of Zwak-Gharb pumping station.

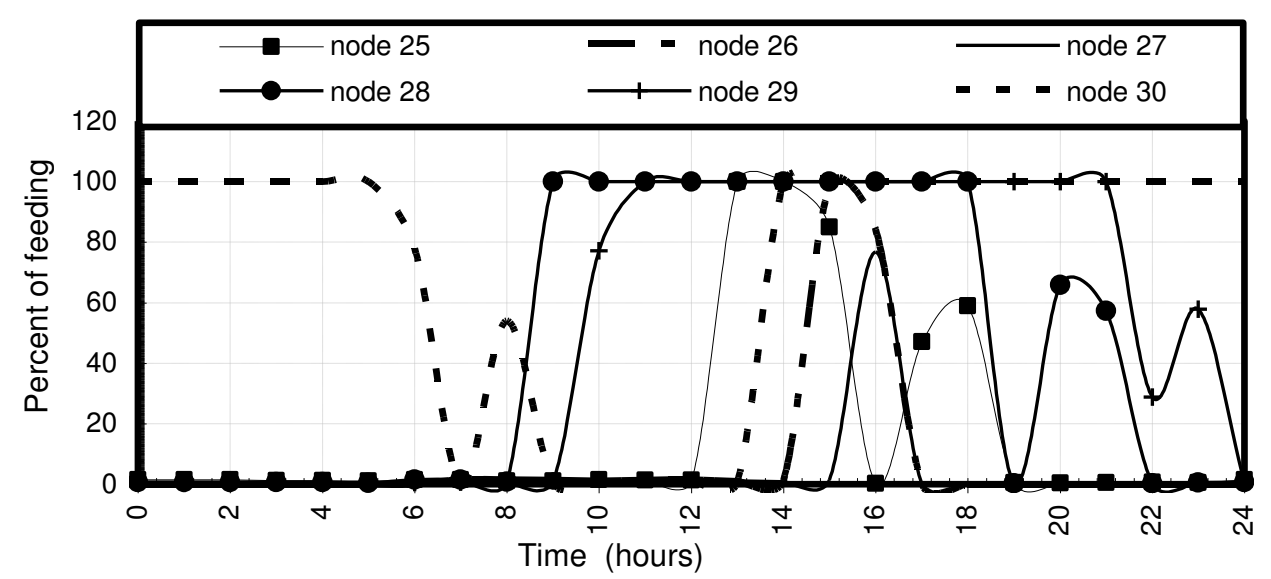

Fig. (20) Transient daily changes of the percent water feeding from Zwak-Gharb pumping station at nodes $25,26,27,28,29$ and 30 


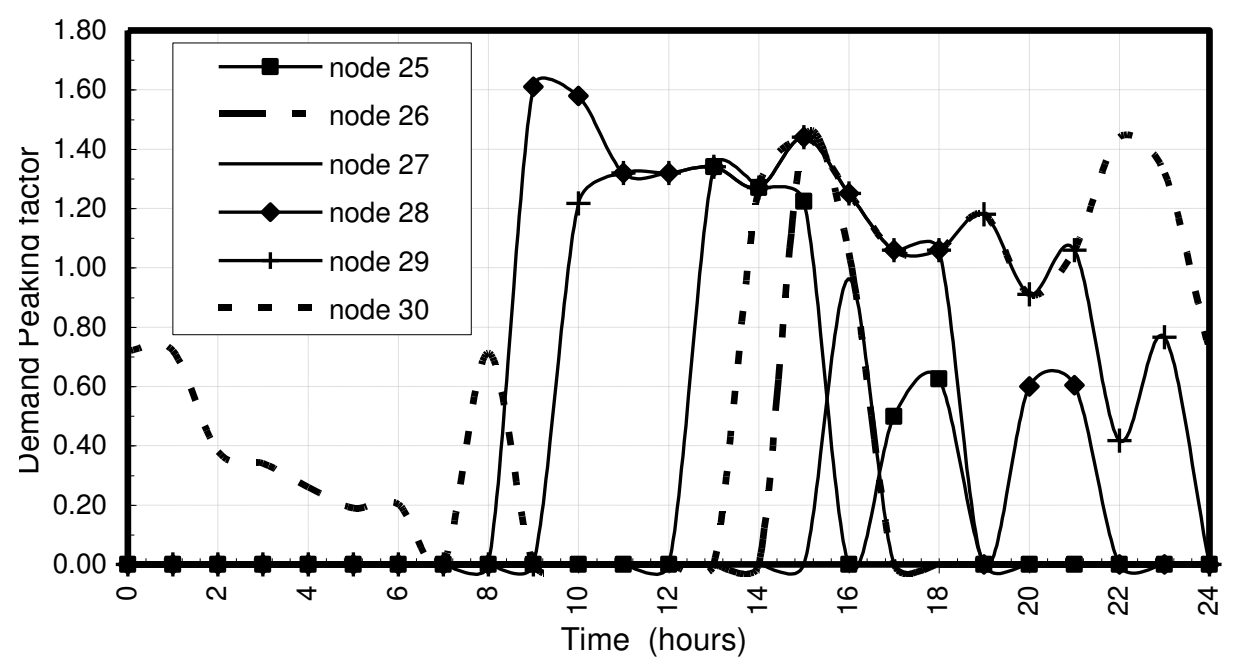

Fig. (21) Diurnal demand curves for nodes 25, 26, 27, 28, 29 and 30 for ZwakGharb sub-network.

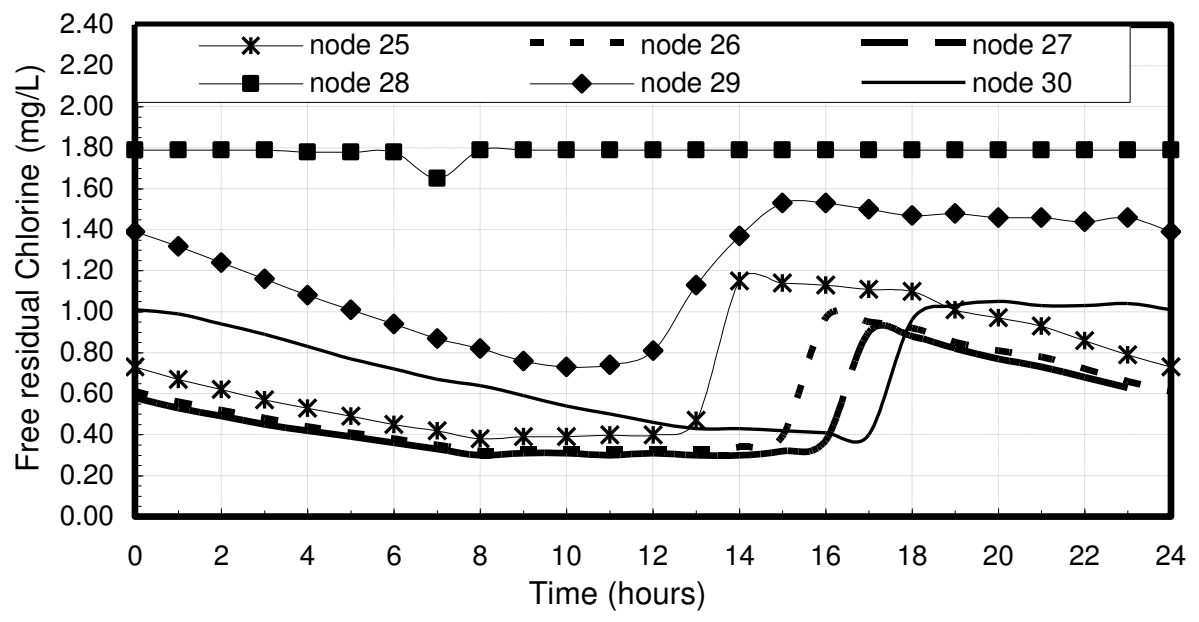

Fig. (22) Free residual chlorine concentration for nodes 25, 26, 27, 28, 29 and 30 for injected dose of $1.80 \mathrm{mg} / \mathrm{L}$ at Zwak-Gharb pumping station.

- The obtained FRCC at the different feeding points of the network (values are given in Table (3)) are used in the extended period simulation of the modified Almonsha water distribution network to get the transient and spatial FRCC through the network. It was found that the FRCC over Almonsha water distribution network are over than the minimum FRCC recommended by WHO. It means that the injected chlorine doses at different water resources are higher than the optimum values. The reason of these high concentrations is that, for the combined network water velocities are higher than those of sub-networks.

Therefore the water reaches faster in the case of the combined modified network and the chlorine decay becomes less. Another simulation was done with reduced injected chlorine doses (17\% of the pervious values) as shown in Table (3). 
Figure (23) shows a contour map of the FRCC over Almonsha DWDN after reduced injected chlorine doses at time 0:00 (critical time). From the figure, it is obvious that the injected FRCC doses are sufficient to keep a FRCC with values more than 0.30 $\mathrm{mg} / \mathrm{L}$ through the whole time of the day over all nodes of the network.

Table (3) Injected chlorine doses at the different water resources before and after reduction by $17 \%$.
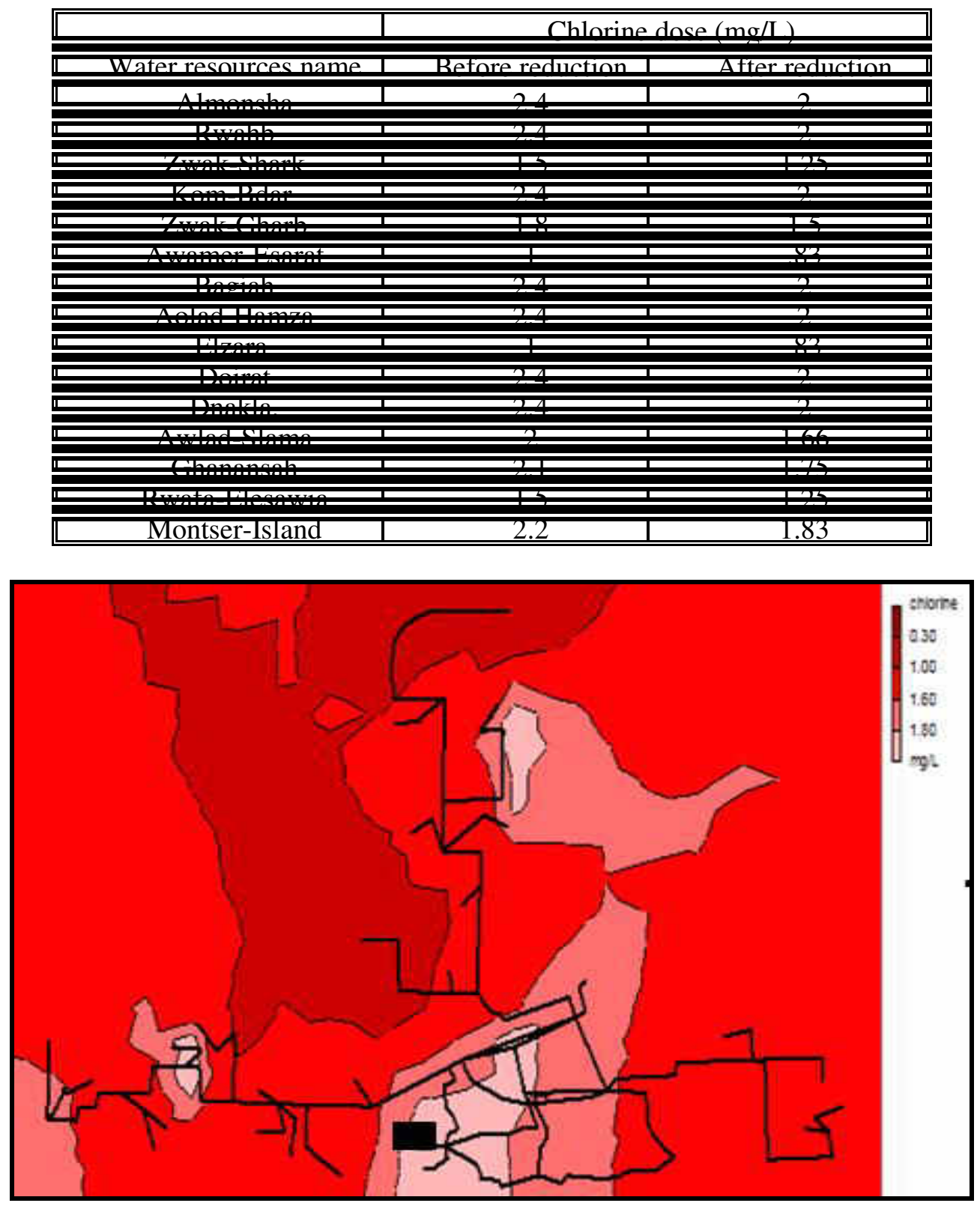

Fig. (23) FRCC contour map for Almonsha water distribution network at 0:00 hours after reduction. 


\section{CONCLUSIONS}

In this study, extended period simulation for several months was used to get the transient changes of FRCC at different sections of Almonsha DWDN. Field and simulated results are compared. Based on the results, the following conclusions are offered:

1. Acceptable methods for measuring $\mathrm{K}_{\mathrm{b}}$ and in-situ $\mathrm{K}_{\mathrm{w}}$ in water distribution systems are presented.

2. Both $\mathrm{K}_{\mathrm{b}}$ and $\mathrm{K}_{\mathrm{w}}$ were found to have an inverse relationship with $\mathrm{C}_{0}$.

3. The difference between the produced and consumed discharges through the day were compared and agreed with amount of the hourly in and out flow of water from the elevated tanks.

4. It is found that $20-30 \%$ of the nodes of Almonsha DWDN have a pressure head less than $36 \mathrm{~m}$ through out the day. The minimum pressure values in the network occur at 8:00 and 16:00 o'clock when the consumption reaches its peak values. Also, a pressure lack occurs at time 0:00 as most of the pumping wells are in the rest time.

5. The first order model for chlorine decay was achieved successfully for Almonsha water distribution system.

6. Extended period simulation for Almonsha DWDN could be performed and it is found that the demand curve is the major factor affecting the FRCC through the network.

7. The magnitude of $\mathrm{C}_{0}$ at the water resources affects on the FRCC at the nodes which take its water from these sources and doesn't affect on nodes which take its water from other sources.

8. In spite of, the injected chlorine dose at source point was constant it is found that the profile of the FRCC follows the demand curve profile. The maximum peak demands were found to be followed by the maximum FRCC.

9. The spatial and transient FRCC through Almonsha DWDN were modeled.

10. Increasing of the injected FRCC at Almonsha WPP to or more than $5 \mathrm{mg} / \mathrm{L}$ doesn't achieve the minimum FRCC at all nodes of the network.

11. A new technique was proposed and used to treat the FRCC lack at the far points of Almonsha network. For this mechanism Almonsha DWDN was divided to several sub-networks and disinfected individually. The obtained safe injected doses of the sub-networks were collected together in a global injected mechanism using the superposition method.

12. With this new mechanism, it is found that the injected FRCC is less in the case of the global injection than in the case of the individual injection with a value of $17 \%$.

13. It is found that, the values of the injected FRCC at the different water resources of Almonsha DWDN various between 0.83 to $2.00 \mathrm{mg} / \mathrm{L}$. These values are found to be sufficient to keep FRCC with values not less than 0.3 $\mathrm{mg} / \mathrm{L}$ through out the day all over the network. 


\section{ACKNOWLEDGMENT}

The authors wish to express their sincere gratitude to Dr. Ali A.M. Gad. Civil Engineering Department, Faculty of Engineering, Assiut University for his help and kind cooperation.

\section{REFERENCES}

1. Ali A.M. Gad. "Improvement of water quality in distribution networks using extended period simulation". First Ain Shams University International Conference on Environmental Engineering, Egypt, April, 2005.

2. Castro, P., Neves, M., Chlorine decay in water distribution systems case study Lousada network. Electron. J. Environ. Agric. Food Chem. ISSN 1579-4377, 2(2). 2003.

3. Center for Information and Decision Support. "Estimation of population at 2008". Statistics Department, Sohag Governorate, Almonsha city, January 2008.

4. Gascon, Laura; Arregui, Francisco; Cobacho, Ricardo., Cabrera Jr., Enrique. "Urban Water Demand in Spanish Cities by Measuring End Uses Consumption Patterns". Congress Water Sources Conference, Celebred in Austin Texas, E.E.U.U, 2004.

5. Hallam, N.B.; West, J.R.; Forster, C.F.; Powell, J.C., Spencer, I. "The decay of chlorine associated with the pipe wall in water distribution systems", Water Research 36, 3479-3488, 2002.

6. Hura, F., West, J.R., Barker, R.A., Forster, C.F., Modelling of chlorine decay in municipal water supplies. Water Research, 33(12), pp. 2735-2746, 1999.

7. James C. Powell; Nicholas B. Hallam; John R. West; Christopher F. Forster\& John Simms, "Factors Which Control Bulk Chlorine Decay Rates", Wat. Res. Vol. 34, No. 1, pp. 117-126, Elsevier Science Ltd. All rights reserved, 1999.

8. Magalhâes, F., Neves, M., Cleaning and disinfection of water supply systems. Electron. J. Environ. Agric. Food Chem. ISSN 1579-4377, 2(2), 2003.

9. Munavalli, G.R., Mohan Kumar, M.S. Modified Lagrangian method for modelling water quality in distribution systems. Water Research, 38, pp.2973-2988, 2004. Cited from Ali [5].

10. Notter, R.H., Sleicher, C.A., The eddy diffusivity in the turbulent boundary layer near a wall. Chem. Eng. Sci., 26, pp. 161-171, 1971.

11. Powell JC. "Modelling chlorine in water distribution networks". Ph.D. thesis, University of Birmingham, 1998.

12. Rossman, L.A., Boulos, P.F., Altman, T., Discrete volume-element method for network water-quality models. J. Water Resour. Plng. and Mgmt, 119(5), pp. 505517, 1993.

13. Rossman, L.A., Clark, R.M., Grayman, W.M., Modelling chlorine residuals in drinking-water distribution systems. J. Env. Eng., 120(4), pp. 803-820, 1994.

14. Rossman, L.A., Boulos, P.F., Numerical methods for modelling water quality in distribution systems: A comparison. J. Water Resour. Plng. and Mgmt, 122(2), pp. 137-146, 1996. 
15. Salgado, R., Tonidi, E., O'Connell, P.E., Extending the gradient method to include pressure regulating valves in pipe networks. Proc. Inter. Symposium on Computer Modelling of Water Distribution Systems. University of Kentucky, May 12-13, 1988.

16. Uber, J., Polycarpou, M., Shang, F., Wang, Z., Autonomous feedback control of booster chlorination systems for distribution system residual maintenance. American Water Works Association and AWWA research foundation, 6666 West Quincy Avenue, Denver, CO 80235, 2001.

\section{نمذجة جودة مياه الشرب في شبكة توزيع المنشاة}

تعتبر جودة مياه الثرب في شبكات التوزيع من الموضوعات الهامة حيث أنها المؤثر الأول علي الصحة

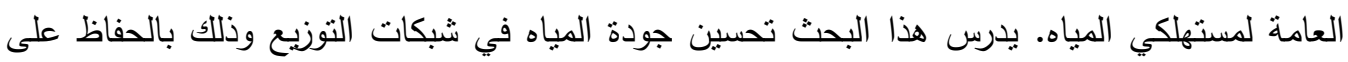

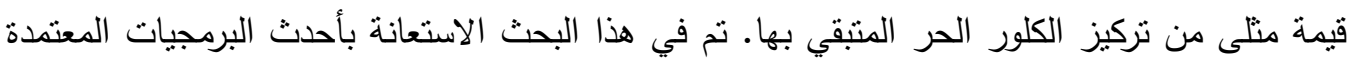

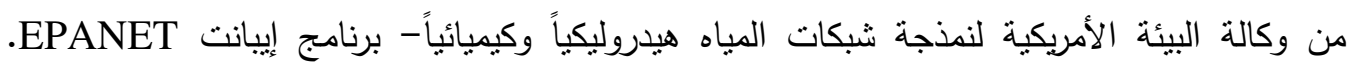

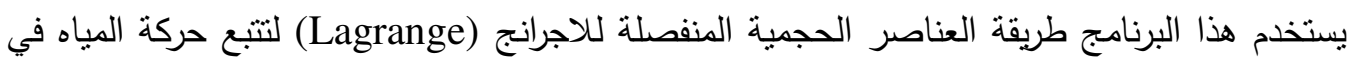

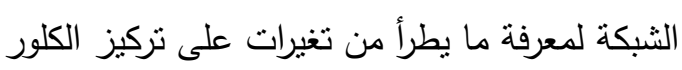

تتتاول هذه الدراسة نمذجة معاملات تلاشي الكلور الحر المتبقي الطبيعية وعلي جدران المواسير بناءا

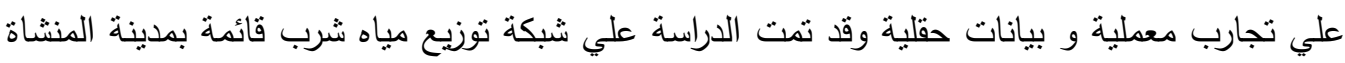

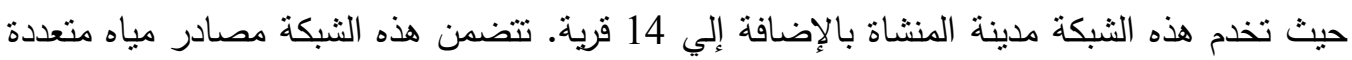

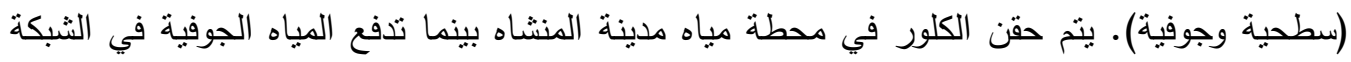

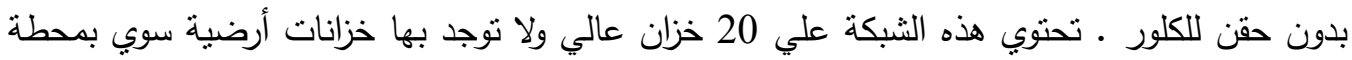

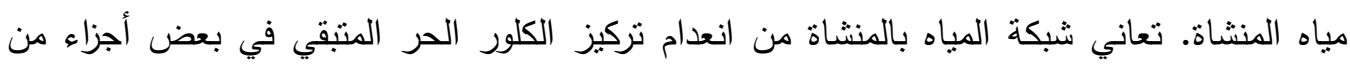

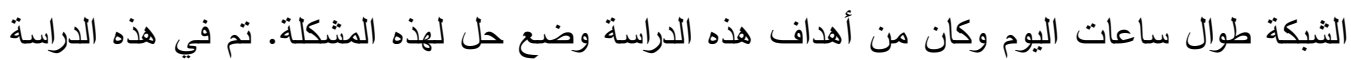
قياس معامل تلاشي الكلور الحر المتبقي الطبيعي وعلي جدران المواسير معمليا وحقليا وقد تم استخدام البيانات الحقلية المجمعة ونتائج التجارب المعملية معا في معايرة (ثبكة المنشاة) باستخدام المحاكاة

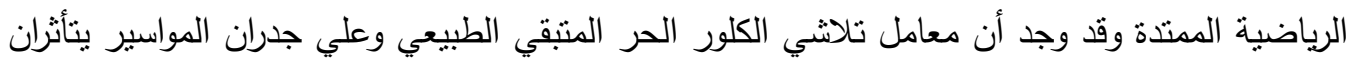

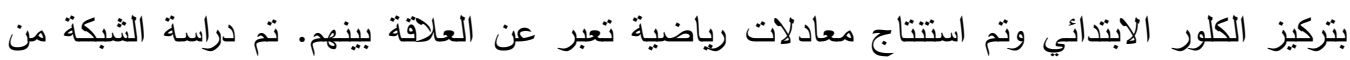

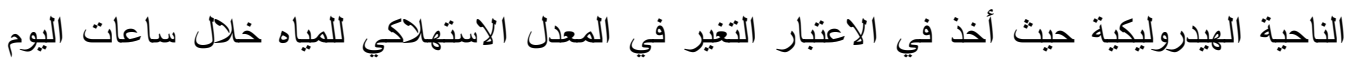
وكذللك الاختلاف في معدل استهلاك الفرد في المدينة عنه في القرية ونم إدخال مصادر المياه المختلفة في الدراسة وكذلك الخزانات الأرضية والخزانات العالية كما تم إدخال التغير في مناسيب الميلة فيلة فياه في آبار المياه الجوفية المغذية للثبكة كما اشتملت المحاكاه علي خصائص المواسير المختلفة في الثبكة. تم التخلص من تأثثر الظروف الابتدائية والمحيطة وذلك بعمل المحاكاة الممتدة لفترة طويلة. تم استخدام 
مناسيب المياه التي تم ملاحظتها في الخزانات العالية كأساس لمعايرة النموذج الرياضي المستخدم. تم

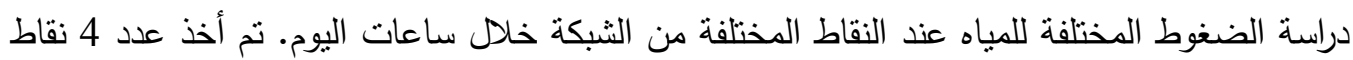
معايرة في أماكن مختلفة من الثبكة حيث تم قياس نركيز الكلور الحر المتبقي عند هذه النقاط في أوقات مختلفة من اليوم ومقارنته بالقيم الناتجة من المحاكاة الرياضية للوصول للقيم الصحيحة للمتغيرات المختلفة في عملية المحاكاة.

تم دراسة تأثثر زيادة نركيز الكلور الحر المتبقي المحقون عند محطة مياه المنشاة علي تركيزه عند النقاط المختلفة للشبكة خلال ساعات اليوم المختلفة وقد وجد أنه لا تزال هناك مناطق منطرفة من الثبكة ينعدم

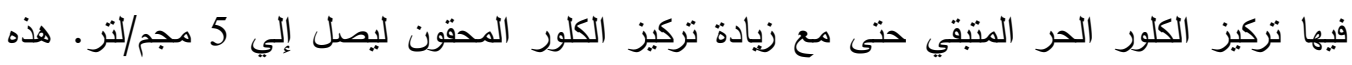

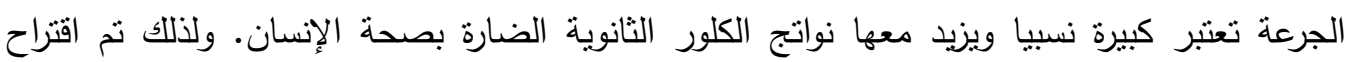

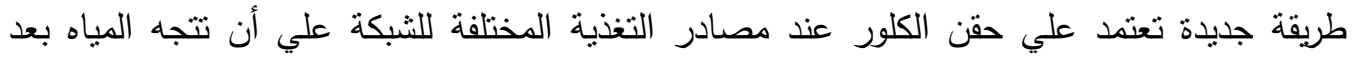
الحقن إلي الخزانات العلوية لإعطاء زمن تلامس كافي للكلور • ولتحديد جرعة الكلور التي يجب حقنه

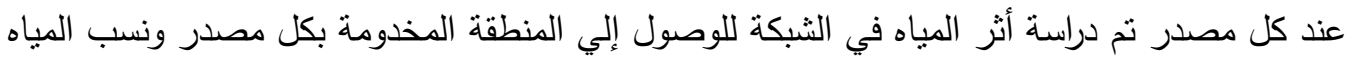

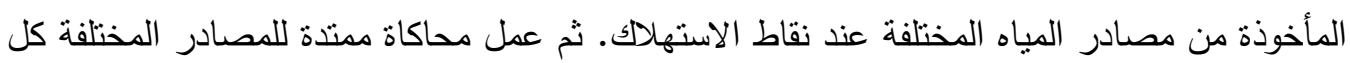
علي حدة بالثبكة التي يخدمها وتم تحديد جرعات الكلور المطلوبة عند كل مصدر بحيث لا يقل تركيز

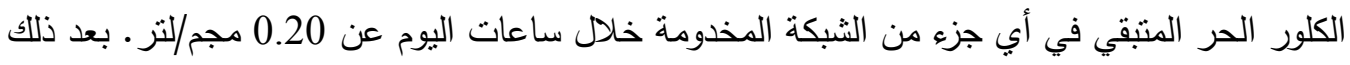
تم تجميع المصادر المختلفة بتركيزات الكلور المحقونة والتي تم تحديدها عند كل مصدر لتعمل جميعها

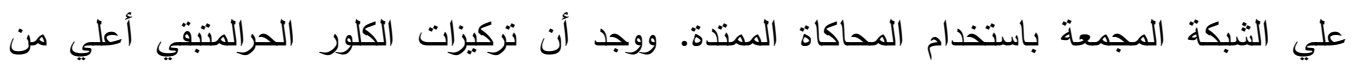
التركيزات التي نتجت عندما كانت هذه المصادر منفصلة عن بعضها البعض لذا تم تقليل الجرعات

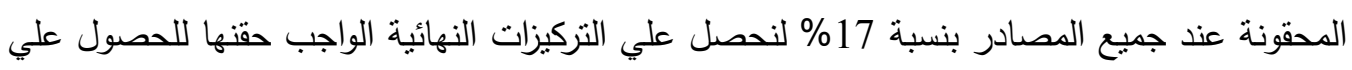

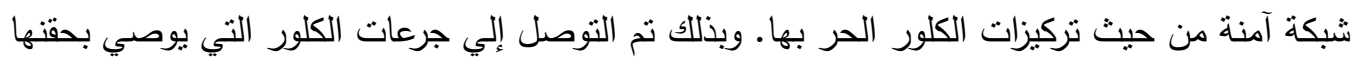

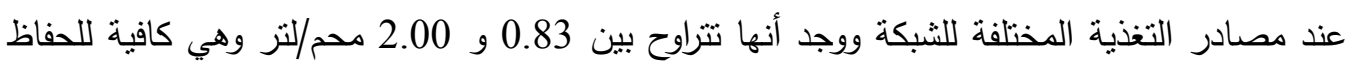
علي تركيز الكلور الحر المتبقي بقيمة أكبر من 0.30 محم/لتز في أي جزء من الثبكة المخدومة خلال

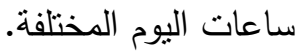

